\title{
Critical challenges in biohydrogen production processes from the organic feedstocks
}

\author{
Ahmed I. Osman ${ }^{1,2}$ (D) Tanmay J. Deka ${ }^{1} \cdot$ Debendra C. Baruah $^{3} \cdot$ David W. Rooney $^{1}$ \\ Received: 28 May 2020 / Revised: 12 August 2020 / Accepted: 14 August 2020 \\ (C) The Author(s) 2020
}

\begin{abstract}
The ever-increasing world energy demand drives the need for new and sustainable renewable fuel to mitigate problems associated with greenhouse gas emissions such as climate change. This helps in the development toward decarbonisation. Thus, in recent years, hydrogen has been seen as a promising candidate in global renewable energy agendas, where the production of biohydrogen gains more attention compared with fossil-based hydrogen. In this review, biohydrogen production using organic waste materials through fermentation, biophotolysis, microbial electrolysis cell and gasification are discussed and analysed from a technological perspective. The main focus herein is to summarise and criticise through bibliometric analysis and put forward the guidelines for the potential future routes of biohydrogen production from biomass and especially organic waste materials. This research review claims that substantial efforts currently and, in the future, should focus on biohydrogen production from integrated technology of processes of (i) dark and photofermentation, (ii) microbial electrolysis cell (MEC) and (iii) gasification of combined different biowastes. Furthermore, bibliometric mapping shows that hydrogen production from biomethanol and the modelling process are growing areas in the biohydrogen research that lead to zero-carbon energy soon.
\end{abstract}

Keywords Biohydrogen $\cdot$ Fermentation $\cdot$ Bio-photolysis $\cdot$ Biowaste $\cdot$ Waste to energy $\cdot$ Microbial electrolysis cell $\cdot$ Gasification $\cdot$ Climate change

$\begin{array}{ll}\text { Nomenclature } \\ \text { ATP } & \text { Adenosine triphosphate } \\ \text { BOD } & \text { Biological oxygen demand } \\ \text { Chl } & \text { Chlorophyll } a+b \\ \text { CCWP } & \text { Concentrated cheese whey permeate } \\ \text { COD } & \text { Chemical oxygen demand } \\ \text { DF } & \text { Dark fermentation } \\ \text { GHG } & \text { Greenhouse gas } \\ \text { HRT } & \text { Hydraulic retention time } \\ \text { HPR } & \text { Hydrogen production rate } \\ \mathrm{HC}^{2} & \text { Hydrocarbon } \\ \mathrm{H}_{2} \mathrm{SO}_{4} & \text { Sulphuric acid }\end{array}$

Ahmed I. Osman

aosmanahmed01@qub.ac.uk

School of Chemistry and Chemical Engineering, Queen's University Belfast, Belfast, Northern Ireland BT9 5AG, UK

2 Chemistry Department, Faculty of Science-Qena, South Valley University, Qena 83523, Egypt

3 Energy Conservation Laboratory, Department of Energy, Tezpur University, Sonitpur 784028, India

$\begin{array}{ll}\text { LCA } & \text { Life cycle assessment } \\ \text { MEC } & \text { Microbial electrolysis cell } \\ \text { NG } & \text { Natural gas } \\ \text { OLR } & \text { Organic loading rate } \\ \text { PNSB } & \text { Purple non-sulphur bacteria } \\ \text { PF } & \text { Photofermentation } \\ \text { SCW } & \text { Second cheese whey } \\ \text { SRT } & \text { Solid retention time } \\ \text { TS } & \text { Total solid } \\ \text { VSS } & \text { Volatile suspended solids } \\ \text { VS } & \text { Volatile solid } \\ \text { WGSR } & \text { Water gas shift reaction } \\ \text { WoS } & \text { Web of Science }\end{array}$

\section{Introduction}

The depletion of fossil-based fuel sources along with their increasing use day by day has created big concerns related to greenhouse gas $(\mathrm{GHG})$ emissions and global warming. Increasing levels of $\mathrm{CO}_{2}$, which is a patent $\mathrm{GHG}$ emission and associated with burning fossil fuel sources, were found 
to exceed $409 \mathrm{ppm}$ [1-3], which is aiding to the global temperature increase $[4,5]$. Moreover, growing industrial and economic development of the modern world is also demanding more sources of clean energy for the near future. The increasing gap between the growing energy demand and necessary energy supply due to at the rising human population has sparked a huge interest in new biofuel research as well as production in recent times [6]. Therefore, from the perspective of alternative energy sources, renewable energy sectors like solar, hydro, wind and biofuels like biodiesel, bioethanol and biohydrogen are finding its use in current development agendas across the world. Recently, hydrogen production by water electrolysis has gained global attention as one of the most promising and eco-friendly energy alternatives. $\mathrm{H}_{2}$ is found to have a high energy content of around $122 \mathrm{~kJ} / \mathrm{g}$, about 2.75 times higher than other $\mathrm{HC}$ fuels [7, 8]. It also possesses wide versatility in its production as well as its applications ranging from fuel-cells to biofertilisers and biofuels. $\mathrm{H}_{2}$ produced from biological sources is known as bio- $\mathrm{H}_{2}$. Hydrogen produces no harmful greenhouse gases upon combustion but only water. Therefore, it is considered one of the energy sources to have the potential to replace part of the conventional fossil-based fuels shortly [9].

As far the production is concerned, fossil fuel is responsible for the majority of hydrogen production, out of which $60 \%$ is produced from dedicated primary hydrogen-producing facilities. It is also reported that around $71.27 \%$ of hydrogen is produced from natural gas (NG), $27.27 \%$ from coal, $0.7 \%$ from petroleum and the remaining $0.7 \%$ from water electrolysis [10-12]. Notably, the hydrogen production from fossil reformation is neither renewable nor carbon neutral as the production process involves high numbers of GHG footprints [4]. $\mathrm{H}_{2}$ production is also achieved with water gas shift reaction (WGSR), thermal decomposition, catalytic oxidation, steam gasification, pyrolysis and autothermal reforming [13, 14]. The recent popularity of waste-to-energy studies also creates an impact on research related to hydrogen production utilising waste materials effectively. Biohydrogen is produced from different organic wastes, thereby solving the issue of waste disposal and energy generation at the same time. Organic waste can be defined as the waste materials that are biodegradable and originates from plants or animals which can be broken into $\mathrm{CO}_{2}$, methane or simple organic molecules [15]. Organic wastes like industrial waste, municipal sewage sludge, solid waste, agricultural residues and poultry waste, manure, have the potential to be used for bioenergy production [16].

However, recent publications suggested further investigations are required on the production of $\mathrm{H}_{2}$ using organic waste materials. The concept of using waste materials from different biological sources to produce environment-friendly biohydrogen can be potentially helpful to tackle the ongoing environmental challenges, while for all $\mathrm{H}_{2}$ production processes (NG reforming, biomass and coal gasification, water electrolysis and others), there are requirements for better reliability and operating flexibility, a reduction in the capital costs and a significant enhancement in the plant efficiencies [17]. Herein, we assessed the routes of biohydrogen production derived from different organic waste materials and highlighted the key factors affecting the yield of biohydrogen. Furthermore, through bibliometric mapping, we suggest steps and future guidelines from the gaps in the literature for the optimisation of hydrogen production from organic waste streams. Overall, this critical review is aimed at helping the academics working in the biohydrogen production research area along with the industrial application and roll-out of a zero-carbon economy. It will also focus on themes that face the development and potential transformation of the biohydrogen market and its future.

\section{Review methodology}

Web of Science (WoS) was utilised herein to obtain the data within the core collection database and then the exported data files; some Boolean operator logic was implemented in the search to find suitable publications and identify evidence gaps in the knowledge and research concerning the biohydrogen topic. A broad timespan of biohydrogen research covering all available year option in the time frame of 1970-2020 is shown in Fig. 1. The bibliometric mapping generated from the WoS core collection is shown in Fig. 1. The overall number of data which was 1539 was exported to the VOSviewer software. Herein, we used the co-occurrence as the type of analysis and all keywords included and the fractional counting method employed. We have direct clusters in Fig. 1 linking specific keywords to general areas such as biohydrogen production. This approach enabled us to visualise the most distinguished keywords in publications in the last 50 years for biohydrogen production. For example, keywords like dark fermentation, water and ethanol production along with lignocellulosic biomass were the most frequently occurring keywords. Other common related keywords to the biohydrogen production are hydrolysis, pyrolysis, gasification, enzymatic hydrolysis, biodiesel production, sludge, microalgae, wastewater, anaerobic digestion, photo-fermentation, glucose, supercritical water and saccharification. Furthermore, the WoS search showed other keywords associated with the production conditions such as pre-treatment, $\mathrm{pH}$, light and temperature. On the other hand, new keywords have been introduced to biohydrogen production recently such as methanol, modelling, storage, fuel-cells, energy recovery, organic waste, bioreactors, light intensity, methanogenesis along with the techno-economic and life cycle assessment (LCA) studies. This implies that areas such as hydrogen production from 


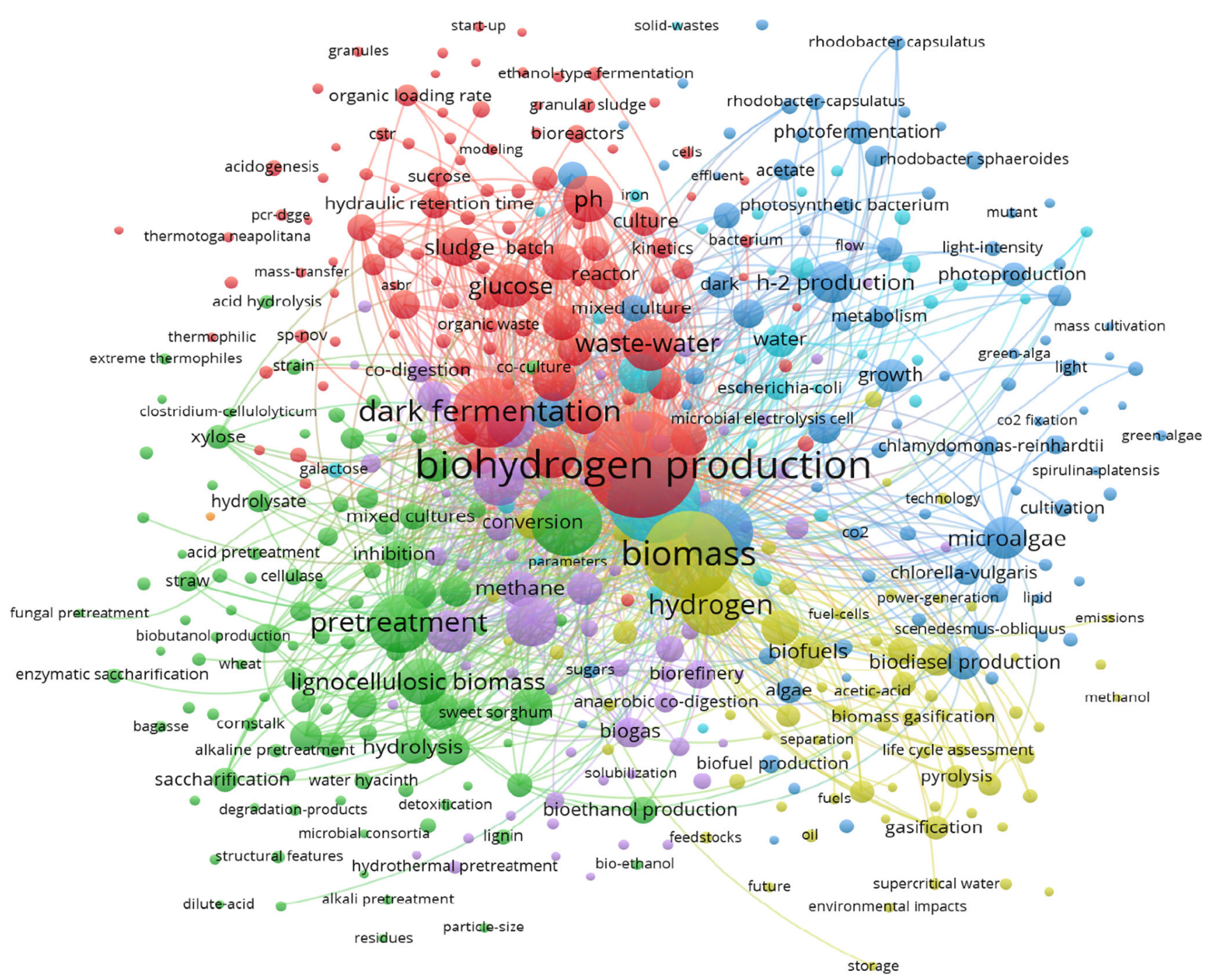

Fig. 1 The bibliometric mapping of biohydrogen production in the last 50 years

methanol need further investigations along with modelling, techno-economic analysis and other research areas.

\section{Production of biohydrogen from organic waste through biological methods}

Although most of the hydrogen production currently is based on fossil fuels, efforts to produce biohydrogen from different bioresiduals such as wastewater or organic wastes are seen to be increasing [18]. Currently, the most popular, widely discussed and developed processes of biohydrogen production using organic waste material are (a) biofermentation (dark fermentation and photofermentation), (b) biophotolysis (direct and indirect), (c) bioelectrochemical system such as microbial electrolysis cells (MEC) and (d) gasification [19, 20]. Table 1 shows the recent status of the different biohydrogen production processes along with their energy conversion efficiencies. Energy conversion efficiency can be defined as the ratio between the useful output of an energy conversion machine/process and energy input [25]. In this section, these processes of biohydrogen production are discussed. Figure 2 shows the different biological processes involved in biohydrogen production. Biohydrogen production with dark fermentation, MEC and biomass gasification possesses high process efficiency, and biomass is the common feedstock in all of the aforementioned processes. Again, photofermentation and biophotolysis can be seen dependant on solar energy for the production of biohydrogen. Different process parameters are associated with all these processes, which have their own importance. Every process has its certain specification and operating conditions along with advantages and disadvantages which are discussed below. 
Table 1 Status of available biohydrogen production technologies

\begin{tabular}{lllll}
\hline Production process & Feedstock & Maturity & $\begin{array}{l}\text { Energy conversion efficiency } \\
(\%)\end{array}$ & [Ref.] \\
\hline Dark fermentation & Biomass & Long term & 4.3 & {$[21]$} \\
Photo fermentation & Biomass + sunlight & Long term & 5.1 & {$[21]$} \\
Bio photolysis & Sunlight + water & Long term & $2.7-4.0$ & {$[22]$} \\
$\begin{array}{l}\text { Microbial electrolysis } \\
\text { cells }\end{array}$ & $\begin{array}{c}\text { Biomass + } \\
\text { electricity }\end{array}$ & Long term & 11.3 & {$[23]$} \\
Biomass gasification & Biomass & Commercial & 88.1 & {$[24]$} \\
\hline
\end{tabular}

\subsection{Fermentation}

Fermentation can be defined as the process of energy generation involving an endogenous electron acceptor from the oxidation of organic waste materials using a number of different microorganisms. The results of fermentation depend on the applied catalyst (isolated enzyme or microorganism producer) and used organic substrate (mostly carbohydrate or protein), along with the process parameters. The character of the fermentation process can be either aerobic or anaerobic [26]. Fermentation of organic waste materials using microorganisms under anaerobic conditions is a good way to produce $\mathrm{H}_{2}$ along with other organic alcohols/acids as by-products. Depending on the necessity of light for the microorganisms, the biofermentation can be divided into two types: (a) dark fermentation and (b) photo fermentation. Dark fermentation is the process of fermentation carried out in dark anaerobic conditions, where breakdown of cellulosic organic feedstock results in the production of biological hydrogen along with organic acids and alcohols [27].
Unlike dark fermentation, photofermentation uses photosynthetic bacteria that use sunlight to produce $\mathrm{CO}_{2}$ and $\mathrm{H}_{2}$ from organic molecules under anaerobic conditions [28]. For improving the yield of biohydrogen, studies related to the integration of both the two fermentation processes can also be found. Figure 3 shows the two types of biofermentation processes used for $\mathrm{H}_{2}$ production.

\subsubsection{Dark fermentation}

Dark fermentation has become one of the well-known technologies for biohydrogen production, which enables the microorganisms to produce $\mathrm{H}_{2}$ in a dark anaerobic condition [29]. However, with the formation of many by-products, the low $\mathrm{H}_{2}$ yield on substrates is a major disadvantage. Equations 1 and 2 show the main reactions that are involved in the dark fermentation process of hydrogen production. Equation 1 shows the reaction for $\mathrm{H}_{2}$ production as a result of the proton reduction by generated electrons from $\mathrm{C}$-source degradation. [NiFe]-hydrogenase and [ $\mathrm{FeFe}]$-hydrogenase are generally involved in such process of $\mathrm{H}_{2}$ formation [30]. A maximum $\mathrm{H}_{2}$

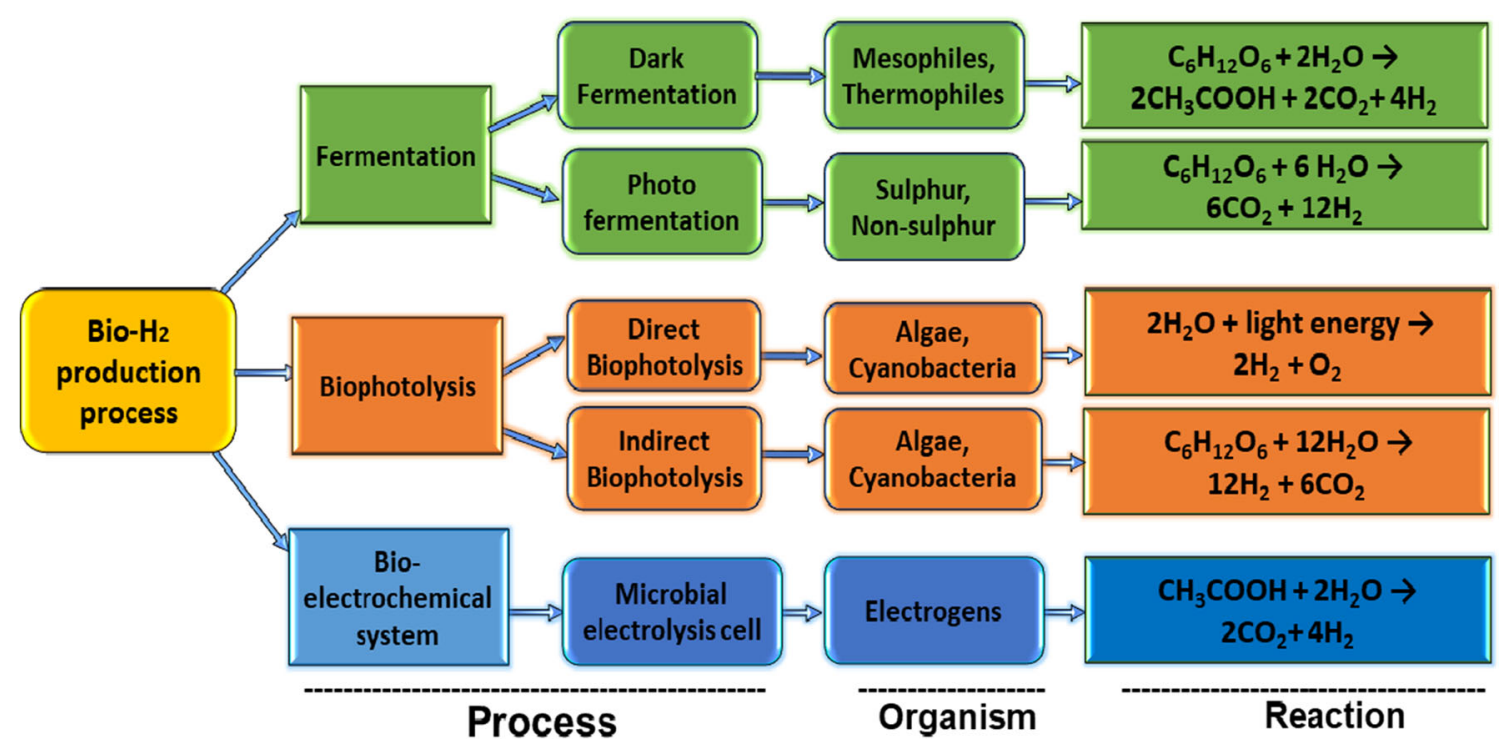

Fig. 2 Overview of the biological biohydrogen production processes 
Fig. 3 a Dark fermentation and b photofermentaion processes during the hydrogen production from organic waste or wastewater
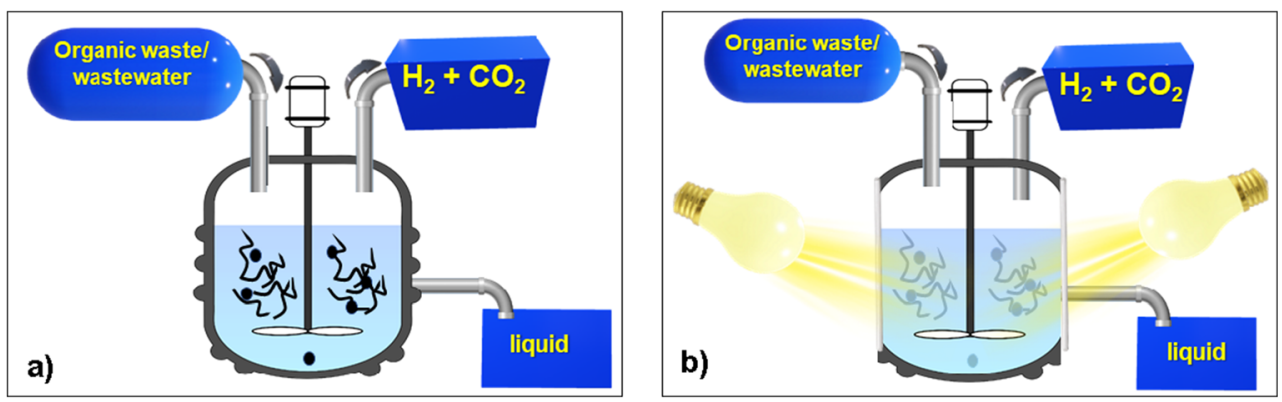

yield of $4 \mathrm{~mol} \mathrm{H}_{2} / \mathrm{mol}$ glucose can be seen to be achievable in the dark fermentation process practically, though Eq. 2 shows a theoretical yield of $12 \mathrm{~mol} \mathrm{H}_{2} / \mathrm{mol}$ glucose [31]. Higher yields can be achieved in thermophilic fermentations. This low yield in dark fermentation is mainly happening due to the production of other by-products such as acetic acid, propionic acid and butyric acid. Equation 3 shows the acetic acid pathway, where the reaction of glucose and two water molecules produce acetic acid $\left(\mathrm{CH}_{3} \mathrm{COOH}\right)$. Similarly, propionic acid can be found to be produced along with acetic acid from glucose, as shown in Eq. 4. Again, Eq. 5 shows the production of butyric acid from glucose reacting with six water molecules [32]. In all the three pathways, $\mathrm{CO}_{2}$ and $\mathrm{H}_{2}$ are seen to be produced in different quantities.

$$
\begin{aligned}
& 2 \mathrm{H}^{+}+2 \mathrm{e}^{-} \leftrightarrow \mathrm{H}_{2} \\
& \mathrm{C}_{6} \mathrm{H}_{12} \mathrm{O}_{6}+6 \mathrm{H}_{2} \mathrm{O} \rightarrow 6 \mathrm{CO}_{2}+12 \mathrm{H}_{2} \\
& \mathrm{C}_{6} \mathrm{H}_{12} \mathrm{O}_{6}+2 \mathrm{H}_{2} \mathrm{O} \rightarrow 2 \mathrm{CH}_{3} \mathrm{COOH}+2 \mathrm{CO}_{2}+4 \mathrm{H}_{2}
\end{aligned}
$$

(Acetic acid pathway)

$$
\mathrm{C}_{6} \mathrm{H}_{12} \mathrm{O}_{6} \rightarrow \mathrm{CH}_{3} \mathrm{COOH}+\mathrm{CH}_{3} \mathrm{CH}_{2} \mathrm{COOH}+\mathrm{CO}_{2}+\mathrm{H}_{2}
$$

(Propionic acid pathway)

$$
\begin{aligned}
& \mathrm{C}_{6} \mathrm{H}_{12} \mathrm{O}_{6}+6 \mathrm{H}_{2} \mathrm{O} \rightarrow 2 \mathrm{CH}_{3} \mathrm{CH}_{2} \mathrm{CH}_{2} \mathrm{COOH}+2 \mathrm{CO}_{2} \\
& +2 \mathrm{H}_{2}
\end{aligned}
$$

(Butyric acid pathway)

Several types of waste with different chemical compositions are seen used as a substrate to produce $\mathrm{H}_{2}$ in the dark fermentation process. Among those, the most widely used waste includes agricultural wastes (viz. rice/wheat/corn straw, animal manure), various wastewater types (viz. distillery wastewater, cheese whey effluent, palm oil mill effluent), food waste, municipal sewage waste and sewage sludge [33]. The sugar or carbohydrate-rich waste substrates tend to produce more $\mathrm{H}_{2}$ compared with lipid or protein-rich substrates. A linear correlation between $\mathrm{H}_{2}$ production and the proportion of carbohydrate-rich waste substrate was also found [34]. Waste like sewage sludge and palm oil mill effluent usually have a low $\mathrm{H}_{2}$ yield compared with other waste due to the high presence of protein or lipid [33].

The pre-treatment is a crucial step in biohydrogen research. Table 2 shows various studies related to pre-treatment methods, like physical (high temperature, ultrasonication and microwave), mechanical (milling and grinding), enzymatic, radiation and hydrothermal pre-treatment for the improvement of $\mathrm{H}_{2}$ yield [49-51]. Different types of substrates need different pre-treatment methods, which can enhance the production efficiency of hydrogen. Pre-treatment of dairy manure can be done mainly with three different methods: (a) acid $(0.2 \% \mathrm{w} / \mathrm{w}$ HCI solution) treatment, (b) alkali $(0.2 \% \mathrm{w} / \mathrm{w} \mathrm{NaOH}$ solution) treatment and (c) $2 \mathrm{~h}$ infrared oven treatment [33, 35]. In the case of sewage sludge, 15 -min boiling at around $100{ }^{\circ} \mathrm{C} \mathrm{com-}$ pletes the pre-treatment [36]. Pre-treatment of rice straw for hydrogen production was found with boiling at $80-100{ }^{\circ} \mathrm{C}$ [37], and in another case, treatment with alkali solution ( $1 \%$ w/w) was found with cellulose hydrolysis after cutting and grinding (2 $\mathrm{mm}$ size) [41]. Distillery wastewater was also found to be pre-treated with $\mathrm{pH}$ neutralisation, centrifugation and sterilisation [39]. Food waste was found to be pre-treated in many ways. Sieving and $6 \mathrm{~h}$ boiling at around $100{ }^{\circ} \mathrm{C}$ of food waste hydrolysate for hydrogen production were reported by Han et al. [42]. Kim et al. [43] mentioned pre-treatment of food waste and sludge mixture with 30-min heating (at $120{ }^{\circ} \mathrm{C}$ ), alkalisation $(3 \mathrm{M} \mathrm{NaOH})$ and acidification $(3 \mathrm{M}$ $\mathrm{HCl})$. Kitchen mill shredding was also applied as a pretreatment method to food waste combined with $5 \%$ glycerol [44].

The $\mathrm{H}_{2}$ yield of $1130 \mathrm{mmol} / \mathrm{g}$ COD was reported for plain palm oil, while an improvement of 2760 and $1880 \mathrm{mmol} / \mathrm{g}$ COD was found for surfactant (Tween 80) and enzyme (Optimase BG) pre-treatment, respectively [52]. Efficient $\mathrm{H}_{2}$ production with lignocellulosic materials like sugarcane bagasse rice/corn/wheat straw and corn stalk from agricultural waste needs pre-treatment as mentioned in several different studies [53, 54]. An increase in $47.3 \%$ of biohydrogen production was seen for pre-treatment of rice husk with a commercial enzyme (Celluclast 1.5 L) compared with that of rice husk without pre-treatment (321 $\mathrm{mL} \mathrm{H}_{2} / \mathrm{g}$ rice husk) [54]. Similarly, $35 \%$ high $\mathrm{H}_{2}$ yield $\left(155 \mathrm{~mL} \mathrm{H}_{2} / \mathrm{g}\right.$ VS) was seen in 


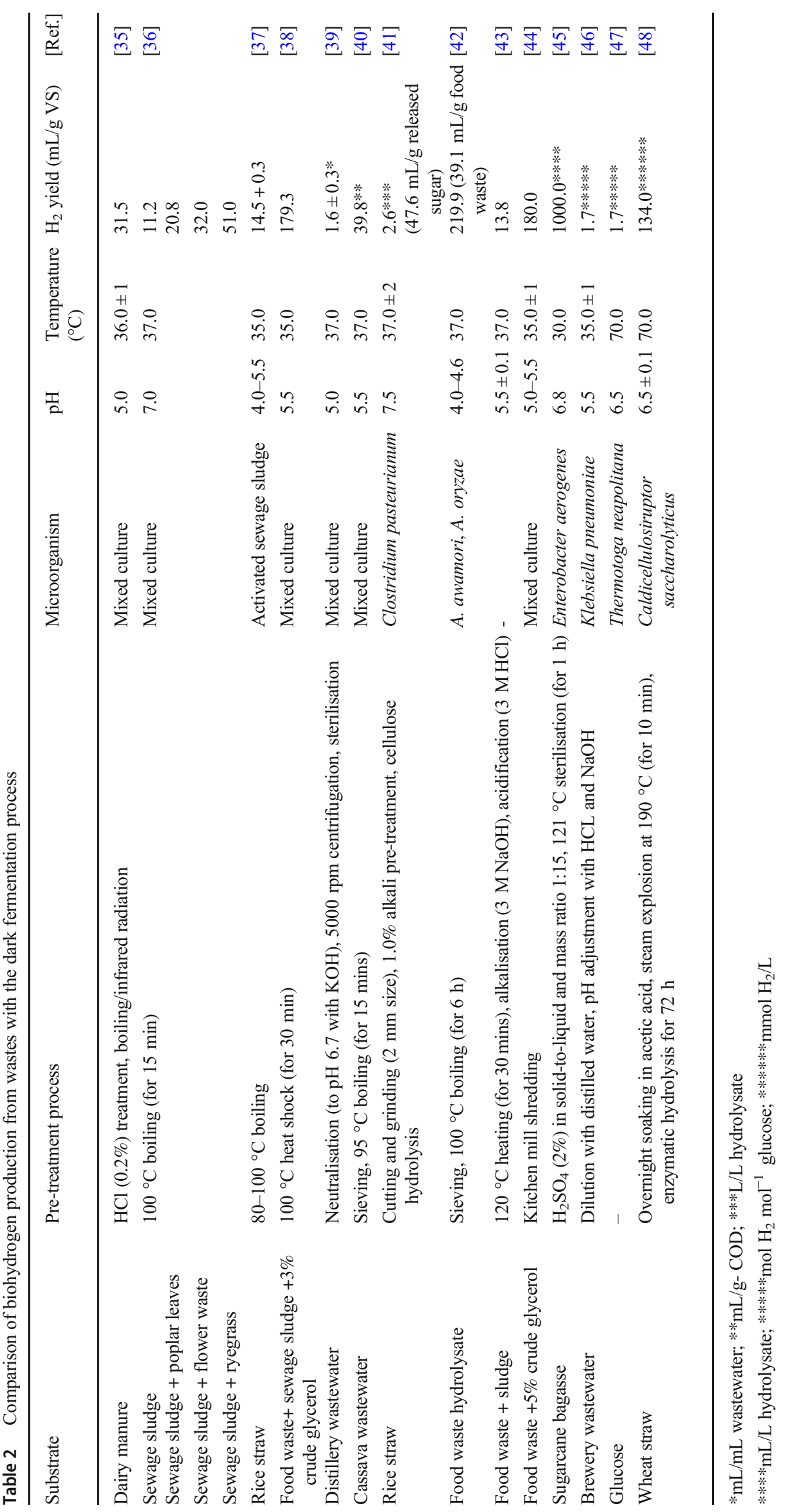


the case of cornstalk pre-treated with lime compared with that of the untreated stalk (115 $\mathrm{mL} \mathrm{H}_{2} / \mathrm{g}$ VS) [55]. Song et al. [56] studied biohydrogen production from an aquatic weed, Alternanthera philoxeroides, pre-treated with $1 \% \mathrm{H}_{2} \mathrm{SO}_{4}$ at $135{ }^{\circ} \mathrm{C}$ for $15 \mathrm{~min}$, using Enterobacter aerogenes ZJU1. The optimum $\mathrm{H}_{2}$ production was found to increase by $59.9 \%$ to reach production of $62.2 \mathrm{~mL} / \mathrm{g}$ with pre-treatment compared with $38.9 \mathrm{~mL} / \mathrm{g}$ VS for the raw material, without pre-treatment. That low hydrogen yield may be due to the utilisation of different feedstocks ( $115 \mathrm{~mL} \mathrm{H}_{2} / \mathrm{g}$ VS). Shao et al. [57] used dilute acid $\left(1 \% \mathrm{H}_{2} \mathrm{SO}_{4}\right)$-pre-treated duckweed biomass for $\mathrm{H}_{2}$ production using dark fermentation. They found a maximum $\mathrm{H}_{2}$ yield of $169.30 \mathrm{~mL} / \mathrm{g}$ dry weight under a temperature condition of $35^{\circ} \mathrm{C}$ and an initial $\mathrm{pH}$ value of 7.0. Acid pre-treatment $(0.2 \% \mathrm{HCl})$ of dairy manure was also seen improving the $\mathrm{H}_{2}$ yield by $36 \%$; further 6.8 and $4.5 \%$ improvement in $\mathrm{H}_{2}$ production from dairy manure was reported for base pre-treatment $(0.2 \% \mathrm{NaOH})$ solution and infrared oven pre-treatment, respectively [35]. Thus, it can be seen that pre-treatment of substrates is highly recommended for good yield of biohydrogen in dark fermentation.

Another important parameter for the dark fermentation biohydrogen yield is the $\mathrm{pH}$ environment value. $\mathrm{pH}$ level in the dark fermentation process is found to influence the metabolic pathway and microorganism activity of the microorganisms and thereby affect the substrate degradation and production efficiency. The $\mathrm{pH}$ levels at the start of operation and during the process were seen carefully maintained in many dark fermentation studies [58-60]. Using dark fermentation of cheese whey wastewater, the highest biohydrogen production was found at $\mathrm{pH} 5.5$ and $\mathrm{pH} 6.5$ for thermophilic and mesophilic conditions, respectively [59]. Xing et al. [35] studied a wide variation in $\mathrm{pH}$ between 4.0 and 12.0 for fermentation of dairy manure. At $\mathrm{pH} 5.0$, they found the highest biohydrogen yield of $31.5 \mathrm{~mL} / \mathrm{g}$ VS. A pH below 4.0 and above 12.0 showed no biohydrogen production.

Hydrogenotrophic methanogens act as one of the major $\mathrm{H}_{2}$-consuming microorganisms which reduced the $\mathrm{H}_{2}$ yield by consuming $\mathrm{H}_{2}$ to produce methane. Therefore, inhibiting the production of hydrogenotrophic methanogens, which acts as an $\mathrm{H}_{2}$-consuming microorganism, is one of the major steps for dark fermentation. Pre-treatment of inoculum is considered for enriching $\mathrm{H}_{2}$-producing bacteria and suppressing $\mathrm{H}_{2}$-consuming methanogens. Since methanogens are strictly anaerobic microorganisms, aeration around the reactor can inhibit the methanogen production and thereby increase the $\mathrm{H}_{2}$ yield [61]. The impact of $\mathrm{pH}$ in the growth of methanogen is another important aspect of biohydrogen yield. It has been reported that methanogens are capable of producing methane by consuming $\mathrm{H}_{2}$ under an optimal $\mathrm{pH}$ range of 7-8 and optimal hydraulic retention time (HRT) of 15-20 days [62]. Kumar et al. [63] attained a hydrogen yield of $29.5 \mathrm{~mL} / \mathrm{g} \mathrm{VS}$ with
pH 5.5 and methanogenic inhibitor from mixed microalgae biomass (Scendesmus and Chlorella).

Production of biohydrogen by dark fermentation is accomplished by various microorganisms that are capable of converting a wide range of organic waste substrates. Based on different living temperatures, these microorganisms are classified as thermophiles $\left(45-65^{\circ} \mathrm{C}\right)$, mesophiles $(25-$ $45^{\circ} \mathrm{C}$ ) and psychrophiles $\left(0-25^{\circ} \mathrm{C}\right)$. The commonly used mesophilic cultures for $\mathrm{H}_{2}$ production are Clostridium and Enterobacter (Clostridium beijerinckii, Clostridium butyricum, Enterobacter aerogenes and Enterobacter asburiae); while the most reported thermophilic one is Thermoanaerobium (Thermoanaerobacterium thermosaccharolyticum) [35]. Again, depending on their growth of metabolism in the presence of oxygen, they are divided as facultative (e.g. E. cloacae, Enterobacter aerogenes, Citrobacter intermedius and Escherichia coli) or obligate bacteria (e.g. C. paraputrificum, Ruminococcus albus and Clostridium beijerinckii) [13, 64]. Facultative bacteria are the organisms that make ATP by aerobic respiration (in the presence of oxygen) and are also capable of anaerobic respiration or fermentation (in the absence of oxygen). On the contrary, obligate bacteria are unable to produce ATP (in the absence of oxygen) and cannot live in the presence of oxygen. Enterobacter and Clostridium are two species of grampositive bacteria for large-scale production of hydrogen for their ability of fast-growing and forming endospores. Lactic bacteria like Klebsiella pneumoniae, Cellulomonas and some thermophilic archaea like Thermotoga neapolitana and Caldicellulosiruptor saccharolyticus were also found showing good results for $\mathrm{H}_{2}$ production through dark fermentation [65].

HRT (hydraulic retention time) acts as one of the important parameters for proper fermentation of substrate and efficient $\mathrm{H}_{2}$ production. The stability of the reactor and utilisation efficiency of the feedstock depends on HRT. Santiago et al. [66] found that HRT and solid retention time (SRT) have a great impact on the biohydrogen production and associated subproducts from organic solid waste (OSW) using a dark fermentation process. A $16 \mathrm{~h}$ of HRT and $55 \mathrm{~h}$ of SRT were found to be the optimum conditions to maximise the biohydrogen production. HRT was found as the main influencing parameter in the whole process. The substrate hydrolysis rate increased with decreasing HRT time. Moreover, substrate hydrolysis-ssolubilisation process time got reduced with an increase in SRT and a decrease in HRT. Fatty acid production was found maximum with long SRT and HRT of $60 \mathrm{~h}$ and $48 \mathrm{~h}$, respectively. Lu et al. [67] studied the effects of HRT and concentration of substrate on the HPR (hydrogen production rate) from glucose in a pilot-scale bioreactor of $3 \mathrm{~m}^{3}$ with three sequential chambers of $1 \mathrm{~m}^{3}$ each. A HRT of $24 \mathrm{~h}$ and substrate concentration of $30 \mathrm{~g} / \mathrm{L}$ with a maximum HPR of $100.2 \mathrm{~mol} / \mathrm{m}^{3}-\mathrm{d}$ were found optimal for the reactor. 
The production of biohydrogen using dark fermentation of two different cheese deproteinisation diary waste streams SCW (second cheese whey) and CCWP (concentrated cheese whey permeate) was studied by Colombo et al. [68]. With an increasing OLR (organic loading rate), $\mathrm{H}_{2}$ production was seen increasing to $3.47 \mathrm{NL} \mathrm{H}_{2} / \mathrm{d}$ and $5.07 \mathrm{NL} \mathrm{H}_{2} / \mathrm{d}$ for SCW and CCWP, respectively. Similarly, organic acid yield was also found higher with increasing OLR (14.6 g/L/d and $12.6 \mathrm{~g} / \mathrm{L} / \mathrm{d}$ for SCW and CCWP, respectively). Table $2 \mathrm{de}-$ scribes different studies of biohydrogen production from wastes using a dark fermentation pathway. It can be seen that combined fermentation of different substrates leads to an increased biohydrogen yield. Moreover, pre-treatment processes such as acid treatment, base treatment, heat treatment and $\mathrm{pH}$ neutralisation have shown a significant impact on the yield of biohydrogen. Most of the studies were found to utilise a mixed culture process for good results.

\subsubsection{Photofermentation}

The production of $\mathrm{H}_{2}$ with photofermentation involves decomposition of organic acids with the aid of light-dependant, sulphur and non-sulphur purple bacteria. A group of bacteria having the ability to do photosynthesis is known as purple sulphur bacteria. Again, purple non-sulphur bacteria (PNSB), commonly known as photobacteria, are a group of photoheterotrophic bacteria capable of degrading several carbon substrates like carbohydrate, organic matter, biowastes and organic acids for the production of $\mathrm{H}_{2}$ [69]. Equations 6 and 7 show the reaction involved with the production of $\mathrm{H}_{2}$ by photofermentive process from glucose and acetic acid, respectively. Oxidation of organic acids, like acetic acid, propionic acid, butyric acid, lactic acid and malic acid, by photofermentive bacteria, produces $\mathrm{H}_{2}$ and $\mathrm{CO}_{2}$. Therefore, to obtain a higher $\mathrm{H}_{2}$ yield, the two-stage dark fermentation process is often followed by a photofermentation process [70]. The energy needed for the growth of microorganisms is gathered from the production of adenosine triphosphate (ATP) using light through photophosphorylation [4]. Batch or continuous photofermentation process can be obtained using an artificial source of light or solar illumination as shown in Fig. $3 \mathrm{~b}$.

$$
\begin{aligned}
& \mathrm{C}_{6} \mathrm{H}_{12} \mathrm{O}_{6}+6 \mathrm{H}_{2} \mathrm{O} \rightarrow 6 \mathrm{CO}_{2}+12 \mathrm{H}_{2} \\
& 2 \mathrm{CH}_{3} \mathrm{COOH}+4 \mathrm{H}_{2} \mathrm{O} \rightarrow 8 \mathrm{H}_{2}+4 \mathrm{CO}_{2}
\end{aligned}
$$

The photofermentation process offers the possibility of high $\mathrm{H}_{2}$ production from a wide variety of substrates including wastewaters (such as olive mill wastewater, dairy wastewater, brewery wastewater) and wastes rich in organic acids (such as dark fermentation effluent, agricultural waste after hydrolysis) $[33,71]$. The best $\mathrm{H}_{2}$-producing microorganism for the photofermentation is PNS (purple non-sulphur bacteria), which include the Rhodobacter species (Rhodobacter capsulatus, Rhodobacter sphaeroides, Rhodovulum palustris and Rhodopseudomonas sulfidophilum) [72]. Some other bacteria used in $\mathrm{H}_{2}$ production using nitrogenase and ATP production are Chlorobium vibrioforme, Allochromatium vinosum, Desulfuromonas acetoxidans, Thiocapsa roseopersicina and Chloroflexus aurantiacus [13]. Hydrogenase and nitrogenase are two different enzymes that help these bacteria to produce $\mathrm{H}_{2}$ from organic acids using solar energy [73]. Nitrogenase are found to be the main enzymes responsible for $\mathrm{H}_{2}$ production in limited- $\mathrm{O}_{2}$ conditions. $\mathrm{NH}_{3}$ is generally produced from $\mathrm{N}_{2}$ by nitrogenase (in largescale production), but in absence of $\mathrm{N}_{2}$, ATP is used along with redundancy by nitrogenase to generate $\mathrm{H}_{2}$ [13], as shown in Eq. 8.

$$
\left(2 \mathrm{H}^{+}+2 \mathrm{e}^{-}+4 \mathrm{ATP} \rightarrow \mathrm{H}_{2}+4 \mathrm{ADP}+\mathrm{Pi}\right) .
$$

Several studies can be found regarding photofermentive $\mathrm{H}_{2}$ production in recent years. Mirza et al. [74] found a wide range of $148-513 \mathrm{~mL} \mathrm{H}_{2} / \mathrm{L}$ photofermentive biohydrogen production using raw sugarcane bagasse with the help of PNSB (purple non-sulphur bacteria) isolated from the paddy rice field Rhodobacter capsulatus-PK. A maximum yield of $96 \mathrm{~mol} \mathrm{H}_{2} / \mathrm{mol}$ sugar was achieved with initial $\mathrm{pH} 7.0 \pm 0.2$ and $10 \%(\mathrm{v} / \mathrm{v})$ inoculum size, at a temperature of $30 \pm 2.0^{\circ} \mathrm{C}$ along with a light intensity of $120-150 \mathrm{~W} / \mathrm{m}^{2}$. The production of $671 \mathrm{~mL} / \mathrm{L}$ of $\mathrm{H}_{2}$ from glucose was also found with this process. For cost reduction of temperature control during summer, Rhodobacter capsulatus-PK was found as a good candidate for photofermentive bio- $\mathrm{H}_{2}$ production. García-Sánchez et al. [75] used Rhodopseudomonas pseudopalustris to produce $\mathrm{H}_{2}$ by tequila vinasses (VT) photofermentation. Compared with synthetic medium, they found a double $\mathrm{H}_{2}$ yield with VT. With the replacement of $\mathrm{H}_{2}$ by $\mathrm{N}_{2}$ compared with unchanged headspace, three-time growth was seen in R. pseudopalustris up to $4.5 \mathrm{~g} / \mathrm{L}$, and the $\mathrm{H}_{2}$ yield also increased to $860 \mathrm{~mL} \mathrm{H}_{2} / \mathrm{L}$. Laurinavichene et al. [39] used PNS bacteria and anaerobic saccharolytic consortium to perform sequential dark photofermentation, which resulted in 17.6 L/L of distillery waste of maximum $\mathrm{H}_{2}$ yield. Machado et al. [76] investigated the influence of milk whey permeate and glucose on the $\mathrm{H}_{2}$ yield using PNS bacteria Rhodobacter capsulatus and Rhodopseudomonas palustris through co-culture. The maximum $\mathrm{H}_{2}$ yield was found to be $287.39 \pm$ $5.75 \mathrm{mmol}$ of $\mathrm{H}_{2} / \mathrm{L}$ day. Keskin and Hallenbeck [77] used beet two major sugar mill waste - black strap and beet molasses for biohydrogen production using photofermentation. The $\mathrm{H}_{2}$ yield found from pure beet sucrose, black strap and beet molasses are $14 \mathrm{H}_{2} / \mathrm{mol}$ sucrose, $8 \mathrm{H}_{2} / \mathrm{mol}$ sucrose and $10.5 \mathrm{~mol} \mathrm{H}_{2} / \mathrm{mol}$ sucrose, respectively. A comparative study of different parameters involved in photofermetive biohydrogen production process is shown in Table 3. The 


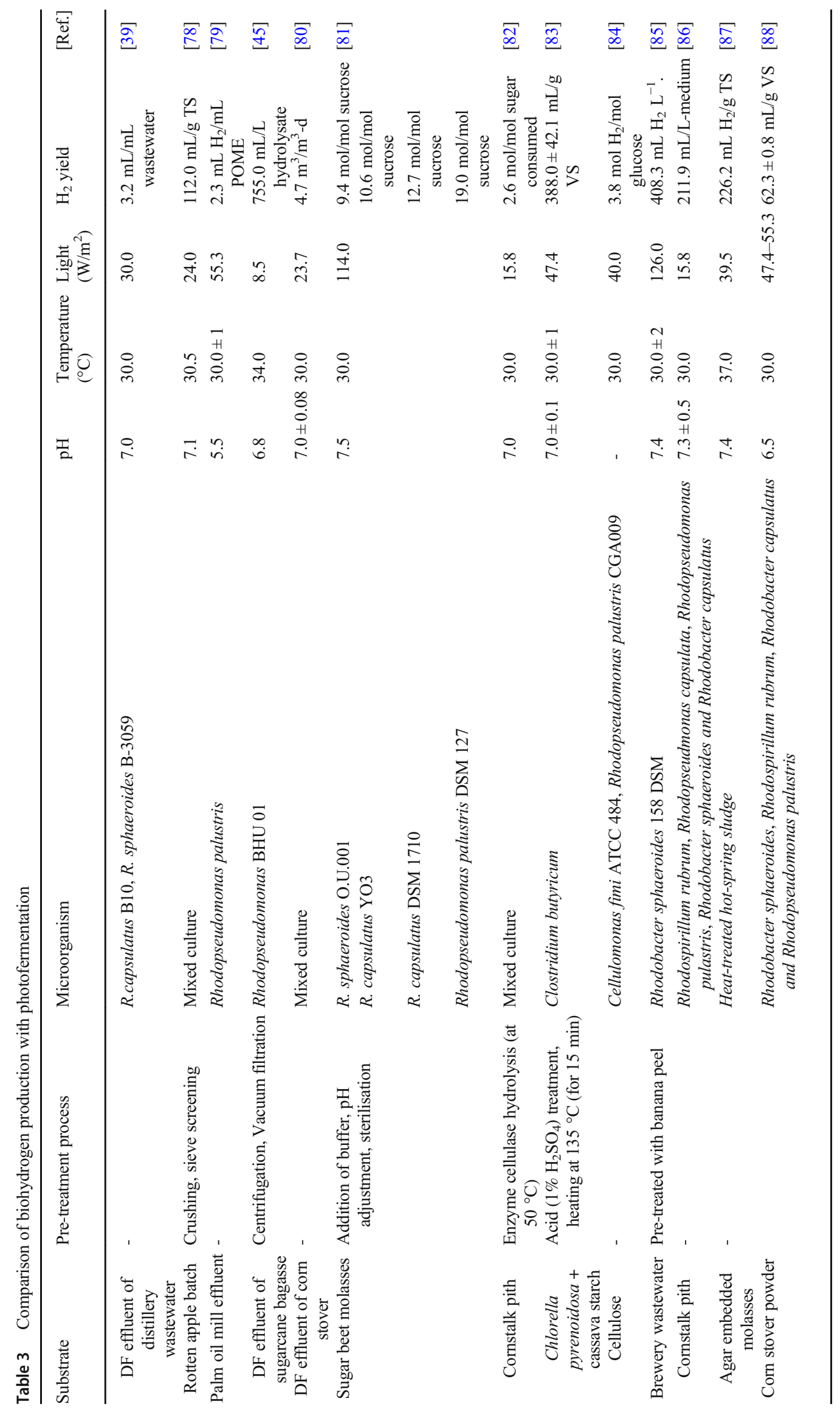


Table 4 Comparison of biohydrogen production by microalgae and cyanobacteria

\begin{tabular}{|c|c|c|c|c|c|c|}
\hline Microalgae/cyanobacteria & Production conditions & $\mathrm{pH}$ & $\mathrm{T}\left({ }^{\circ} \mathrm{C}\right)$ & $\begin{array}{l}\text { Light } \\
\left(\mathrm{W} / \mathrm{m}^{2}\right)\end{array}$ & $\mathrm{H}_{2}$ yield & [Ref.] \\
\hline $\begin{array}{l}\text { C. reinhardtii cbn } 1-48 \text { (spectral } \\
\text { selective activation of PSI) }\end{array}$ & $\begin{array}{l}\text { Tris-acetate-phosphate medium, } \\
5 \% \mathrm{CO}_{2} \text {, dark anaerobic } \\
\text { adaptation }\end{array}$ & 7.2 & $25.0 \pm 2$ & 426.6 & $40.2 \mathrm{~mL} / \mathrm{kg} \mathrm{DCW}$ & [92] \\
\hline C. reinhardtii Dang $137^{+}$(magnesium deprived) & TAP medium & 7.7 & 25.0 & 34.1 & $6.0 \mathrm{mmol} / \mathrm{L}$ & [93] \\
\hline Chlorella sp. IOAC707S (phosphorous deprived) & TAP-seawater medium & 7.2 & 28.0 & 10.7 & $38.0 \mathrm{~mL} / \mathrm{L}$ & [94] \\
\hline Lyngbya sp. (benzoate as a carbon source & $\begin{array}{l}\text { Basal medium, } 600 \mathrm{mg} / \mathrm{l} \text { benzoate } \\
\text { at late exponential phase }\end{array}$ & 7.4 & 32.0 & 31.6 & $\begin{array}{l}\text { 17.1 } \mu \mathrm{mol} \mathrm{H} / 2 / g ~ C h l \\
\mathrm{a} / \mathrm{h}\end{array}$ & [95] \\
\hline Nostoc PCC $7120 \Delta$ hupW & $\begin{array}{l}\text { BG110 medium, supplied with a } \\
\text { mixture of red and white light, } \\
\text { altering } 100 \% \mathrm{Ar} \text { and } \mathrm{Ar} / \mathrm{N} 2 \\
(20 / 80)\end{array}$ & 8.0 & 30.0 & 18.8 & $6.2 \mathrm{ml} / \mathrm{L} / \mathrm{h}$ & {$[22]$} \\
\hline C. reinhardtii (CC124) & Sulphur-free TAP medium & 7.7 & - & 64.0 & $1.3 \pm 0.1 \mathrm{~mL} / \mathrm{L} / \mathrm{h}$ & {$[96]$} \\
\hline $\begin{array}{l}\text { C. reinhardtii CC-425 strain (phosphorus and sulphur } \\
\text { deprived) }\end{array}$ & TAP medium, TAP-sulphur & - & - & 121.6 & $0.8 \mu \mathrm{mol} / \mathrm{mg} \mathrm{Chl} / \mathrm{h}$ & [97] \\
\hline
\end{tabular}

temperature variation clearly shows that the optimum operating temperature range of photofermentation lies between 28 and $32{ }^{\circ} \mathrm{C}$. Further, the highest $\mathrm{H}_{2}$ yield with photofermentation can be seen with a neutral $\mathrm{pH}$ value (around 7) in most of the cases [89]. Moreover, the light intensity and HRT play a very important role in the $\mathrm{H}_{2}$ yield in photofermentation. Because of the slow metabolic activity of PNSB in photofermentation, usually longer HRT can be seen compared with dark fermentation [33]. Moreover, light source plays a very important role in the growth of microorganisms as well as the $\mathrm{H}_{2}$ yield in photofermentation, which can be easily seen in Table 3 .

\subsection{Biophotolysis}

Biophotolysis or water-splitting photosynthesis is the process in which by using oxygenic photosynthetic microorganisms like cyanobacteria and green microalgae, $\mathrm{H}_{2}$ can be produced with only sunlight and water. For this process, FeFe-hydrogenase is needed for the green microalgae application and heterocystous cyanobacteria nitrogenase finds its use [13]. Biophotolysis $\mathrm{H}_{2}$ production can be divided into two ways: (a) direct biophotolysis and (b) indirect biophotolysis.

\subsubsection{Direct biophotolysis}

In the direct biophotolysis, photosynthetic microorganisms like green algae and cyanobacteria absorb 400-700 nm solar radiation for their cell growth [90]. After accepting solar radiation, the microorganisms can evolve hydrogen through nitrogenase or hydrogenase. In direct biophotolysis, water splitting occurs with a light energy of $680 \mathrm{~nm}$ wavelength to produce protons, electrons and oxygen as shown in Eq. 9. The electrons derived from Eq. 9 are transferred through PS II and PS I to a potentially sufficient amount for ferredoxin $(\mathrm{Fd})$ reduction. The reduced $\mathrm{Fd}$ then is used for the reduction of hydrogenase enzyme NADP+ to NADPH, which is responsible for the production of $\mathrm{H}_{2}$, as shown in Eq. 10 [13].

$$
\begin{aligned}
& 2 \mathrm{H}_{2} \mathrm{O}+\text { light energy } \rightarrow \mathrm{O}_{2}+4 \mathrm{H}^{+}+4 \mathrm{e}^{-} \\
& 2 \mathrm{H}^{+}+2 \mathrm{Fd}(\mathrm{re}) \leftrightarrow \mathrm{H}_{2}+2 \mathrm{Fd}(\mathrm{ox})
\end{aligned}
$$

\subsubsection{Indirect biophotolysis}

Indirect biophotolysis involves a two-step photosynthetic conversion of light energy to carbohydrates as a form of chemical energy. As shown in Eq. 11, in the first step, using light energy $\mathrm{O}_{2}$ and carbohydrate (starch and glycogen in green algae and cyanobacteria, respectively) are produced [91]. By limiting $\mathrm{N}_{2}$ during Eq. 10, an increase in carbohydrate yield and reduction in $\mathrm{O}_{2}$ amount can be achieved, which subsequently is advantageous for high $\mathrm{H}_{2}$ yield. The second step involves the conversion of carbohydrate to $\mathrm{CO}_{2}$ and $\mathrm{H}_{2}$ with light energy under an anaerobic condition with less $\mathrm{O}_{2}$, as shown in Eq. 12 and Eq.13. [73].

$$
\begin{aligned}
& 6 \mathrm{CO}_{2}+12 \mathrm{H}_{2} \mathrm{O}+\text { light energy } \rightarrow \mathrm{C}_{6} \mathrm{H}_{12} \mathrm{O}_{6}+6 \mathrm{O}_{2} . \\
& \mathrm{C}_{6} \mathrm{H}_{12} \mathrm{O}_{6}+2 \mathrm{H}_{2} \mathrm{O} \rightarrow 4 \mathrm{H}_{2}+2 \mathrm{CH}_{3} \mathrm{COOH}+2 \mathrm{CO}_{2} . \\
& 2 \mathrm{CH}_{3} \mathrm{COOH}+4 \mathrm{H}_{2} \mathrm{O}+\text { light energy } \rightarrow 8 \mathrm{H}_{2}+4 \mathrm{CO}_{2}
\end{aligned}
$$

Many recent research studies can be found producing biohydrogen from green algae and cyanobacteria as shown in Table 4. Kossalbayev et al. [98] studied the biohydrogen yield using four different cyanobacteria strains: (a) Desertifilum sp. IPPAS B-1220, (b) Synechocystis sp. PCC 6803, (c) Phormidium corium B-26 and (d) Synechococcus 

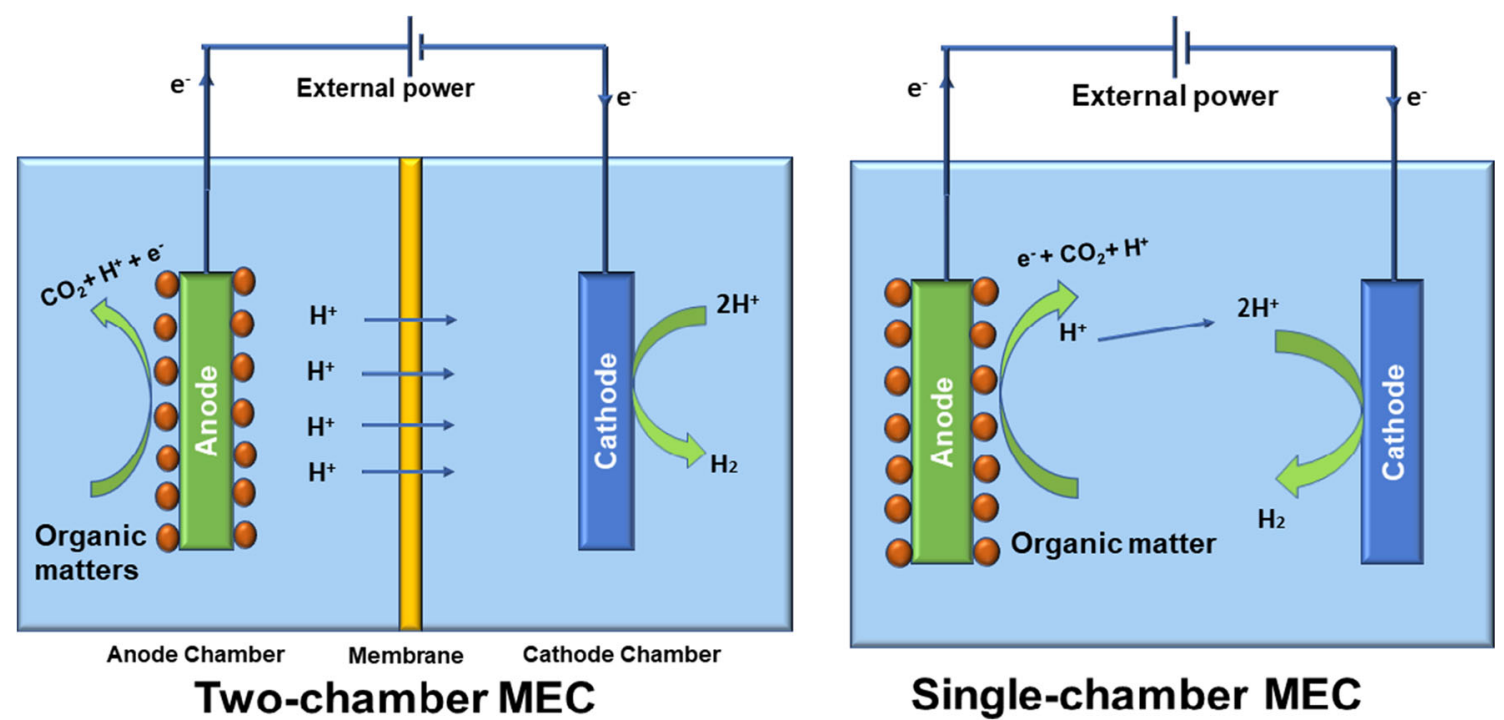

Fig. 4 Schematic diagram of two-chamber and single-chamber MEC (microbial electrolysis cells)

sp. I12. Within 120 dark hours, Synechocystis sp. PCC 6803 was seen to have a high $\mathrm{H}_{2}$ accumulation of $0.037 \mu \mathrm{mol} \mathrm{H}_{2}$ / $\mathrm{mg} \mathrm{Chl} / \mathrm{h}$. Again, at $166 \mathrm{~h}$ of light incubation, Desertifilum $\mathrm{sp}$. IPPAS B-1220 was seen to produce $0.229 \mu \mathrm{mol} \mathrm{H}_{2} / \mathrm{mg} \mathrm{Chl} / \mathrm{h}$. Hoshino et al. [92] investigated the $\mathrm{H}_{2}$ and $\mathrm{O}_{2}$ yield through the implementation of PS I light in Chlamydomonas reinhardtii mutant strains. In a continuous 18 h PS I light supply, $\mathrm{H}_{2}$ production was seen at $220 \mathrm{dm}^{3} / \mathrm{kg}$ and $176 \mathrm{dm}^{3} /$ $\mathrm{kg}$ for cbn 1-48 (a mutant with a chlorophyll-b deficiency) and $\mathrm{VHL}^{\mathrm{R}}$-S4 (a mutant with high light tolerance), respectively. The highest $\mathrm{H}_{2}$ production of $366 \mathrm{dm}^{3} / \mathrm{kg}$ was seen in cbn 1-48 under $1.5 \mathrm{~h}$ light and dark iteration with PS I-light. Esquível et al. [99] also studied the $\mathrm{H}_{2}$ yield with biophotolysis by Chlamydomonas reinhardtii wild and mutant strains. Kosourov et al. [100] found a maximum of $9.4 \mu \mathrm{mol} / \mathrm{mg}$ chlorophyll// $\mathrm{h}_{2}$ yield with a $7.7 \mathrm{pH}$ by using C. reinhardtii. Huesemann et al. [101] studied $\mathrm{H}_{2}$ production using Plectonema boryanum (nonheterocystous nitrogenfixing cyanobacterium) under continuous illumination, where the maximum $\mathrm{H}_{2}$ production rate was found as $0.18 \mathrm{~mL} /$ $\mathrm{mg}$ day with a $1 \mathrm{mM}$ initial nitrate concentration under $100 \mu \mathrm{mol} / \mathrm{m}^{2}$ light intensity.

\subsection{Bioelectrochemical system}

Bioelectrochemical system of $\mathrm{H}_{2}$ production from a wide variety of substrates using microbial electrolysis cells (MEC) is a new technology getting popularity in recent years. MEC technology is also known as biocatalysed electrolysis cells or electrofermentation [13]. As shown in Fig. 4, the MEC system has two electrodes, cathode and anode, which can either be placed in the same single chamber (single-chamber MEC) or be separately placed in two individual chambers (two-chamber MEC). In the two-chamber MEC, to separate the two chambers, commonly a proton exchange membrane is used. Other recently developed membranes include a charge-mosaic membrane, cation/anion exchange membrane and bipolar membrane [102]. In the two-chamber MEC, the anode chamber is filled with the organic wastewater, while the cathode chamber can be filled with different solutions (like moderate acidified water, phosphate-buffered solution, bicarbonate buffers and salt solutions) [103, 104]. The main working process in both the MEC types is the same. Electrons get generated by the oxidation of organic matter in the anode, which are transported to the anode. Then, they are transported to the cathode where upon combining with protons, $\mathrm{H}_{2}$ gets generated [33].

The initial MEC systems comprised of two chambers avoiding interference of electrodes, which produced highpurity $\mathrm{H}_{2}$ [105]. MEC acts as an anaerobic system sensitive to oxygen. Equations 14-16 show the production of $\mathrm{H}_{2}$ using MEC for acetate. In addition to a potential generated by microorganisms $(-0.300 \mathrm{~V})$, MEC needs a small external potential of more than $0.110 \mathrm{~V}$ for the production of $\mathrm{H}_{2}$ [106]. The external power source use of the battery is generally considered, but the use of renewable power generated from solar, wind, MFCs and waste heat can be seen [19, 107].

Anode : $\mathrm{CH}_{3} \mathrm{COOH}+2 \mathrm{H}_{2} \mathrm{O} \rightarrow 2 \mathrm{CO}_{2}+8 \mathrm{e}^{-}+8 \mathrm{H}^{+}$

Cathode : $8 \mathrm{e}^{-}+8 \mathrm{H}^{+} \rightarrow 4 \mathrm{H}_{2}$

Overall : $\mathrm{CH}_{3} \mathrm{COOH}+2 \mathrm{H}_{2} \mathrm{O} \rightarrow 2 \mathrm{CO}_{2}+4 \mathrm{H}_{2}$

Many different substrates were found in use for MEC to produce $\mathrm{H}_{2}$. Some common pure chemical substrates used are butyrate, glucose, acetate and glycol. However, different waste streams like poultry farming wastewater [108, 109], domestic wastewater $[105,110,111]$, waste activated sludge $[112-114]$ and industrial wastewater $[115,116]$ are used in 
Table 5 A comparison study of working parameters of MEC

\begin{tabular}{|c|c|c|c|c|c|c|}
\hline Type of waste & Type of MEC reactor & Temperature $\left({ }^{\circ} \mathrm{C}\right)$ & $\mathrm{pH}$ & $\begin{array}{l}\text { External } \\
\text { voltage }(\mathrm{V})\end{array}$ & $\begin{array}{l}\mathrm{H}_{2} \text { yield } \\
(\mathrm{L} / \mathrm{L} / \mathrm{d})\end{array}$ & [Ref.] \\
\hline Domestic wastewater & $\begin{array}{l}6 \text { two-chamber cassettes } \\
\text { (Pilot-scale) MEC }\end{array}$ & $13.5 \pm 1.2-21.0 \pm 1.2$ & $\begin{array}{l}7.0 \pm 0.4 \text { (influent) } \\
6.7 \pm 0.2 \text { (effluent) }\end{array}$ & 1.1 & $0.02 \mathrm{~L} / \mathrm{L} / \mathrm{d}$ & [105] \\
\hline Swine manure wastewater & Two-chamber MEC & $25.0 \pm 2$ & 7.0 & 1.2 & $5.1 *$ & [108] \\
\hline Waste activated sludge & Single-chamber MEC & 20.0 & $7.0 \pm 0.2$ & 0.6 & $90.6^{* *}$ & [113] \\
\hline $\begin{array}{l}\text { Effluent from DF sugar beet } \\
\text { juice wastewater }\end{array}$ & Two-chamber MEC & 25.0 & 7.2 & 0.4 & $306.0^{* * *}$ & [115] \\
\hline $\begin{array}{l}\text { Food processing wastewater } \\
\text { (FP) }\end{array}$ & Single-chamber MEC & 30.0 & 7.3 & 0.7 & 0.4 & [116] \\
\hline $\begin{array}{l}\text { Chemical industrial wastewater } \\
\text { (IN) }\end{array}$ & & & 6.4 & & 0.6 & \\
\hline Cornstalk wastewater & Two-chamber MEC & $25.0 \pm 2$ & 7.0 & 1.0 & $3.9 * * * *$ & [119] \\
\hline
\end{tabular}

*mmol/g COD; **mL/g VSS; ***mL/g COD; ****mL/L/d

MEC. Tenca et al. [116] found a higher $\mathrm{H}_{2}$ yield for methanolrich industrial wastewater compared with food processing wastewater, but the food processing wastewater was found to have high $\mathrm{H}_{2}$ selectivity of around $86 \%$ compared with that of industrial chemical wastewater. Improvement in the $\mathrm{H}_{2}$ yield can be seen in many studies with MEC coupled with anaerobic digestion and/or dark fermentation $[114,115,117$, 118]. Huang et al. [117] studied the $\mathrm{H}_{2}$ production from food waste from anaerobic digestion coupled with the singlechamber MEC. They found $511.02 \mathrm{~mL} \mathrm{H}_{2} / \mathrm{g}$ VS of the $\mathrm{H}_{2}$ yield from the continuous AD-MEC process which was much higher than the $\mathrm{AD} \mathrm{H}_{2}$ yield (49.39 $\mathrm{mL} \mathrm{H}_{2} / \mathrm{g} \mathrm{VS}$ ). Dhar et al. [115] studied the $\mathrm{H}_{2}$ yield from sugar beet juice using an integrated MEC dark fermentation process. Overall $\mathrm{H}_{2}$ yield with the integrated process was found to be $25 \%$ of initial chemical oxygen demand (COD) $\left(6 \mathrm{~mol} \mathrm{H}_{2} / \mathrm{mol} \mathrm{hexose}_{\text {added }}\right)$ which is much higher than that of dark fermentation alone (13\% of initial COD). Li et al. [118] also found a maximum $\mathrm{H}_{2}$ yield of $387.1 \mathrm{~mL} \mathrm{H}_{2} / \mathrm{g}$ corn stalk with the integrated dark fermentation MEC process, which was around thrice that from dark fermentation alone with $20 \mathrm{~g} / \mathrm{L}$ of corn stalk input and 7.0 initial $\mathrm{pH}$ value. Lu et al. [114] also found twice $\mathrm{H}_{2}$ yield with waste activated sludge coupled with MEC (Table 5).

Raw materials, temperature, $\mathrm{pH}$ and operating voltage play an important role in determining the $\mathrm{H}_{2}$ yield in MEC. However, with MEC, it has been noticed that operating temperatures from 0 can be used in producing biohydrogen from wastewater without having significant effects on the yield. An $\mathrm{H}_{2}$ yield of $0.015 \mathrm{~L} / \mathrm{L} / \mathrm{d}$ was found with domestic wastewater within an operating temperature range of 13 to $21^{\circ} \mathrm{C}$ [105]. Heidrich et al. [120] found improvement in exoelectrogen activities with temperature while studying MEC with domestic wastewater within $1-22{ }^{\circ} \mathrm{C}$. Patil et al. [121] also demonstrated operating MEC with wastewater within 0 to $45{ }^{\circ} \mathrm{C}$. Better performance was seen within $10{ }^{\circ} \mathrm{C}$ to $20^{\circ} \mathrm{C}$, thereby showing the advantages of MEC over other fermentative biohydrogen production processes. Again, an increasing $\mathrm{H}_{2}$ yield with increasing external applied voltage was reported in the literature [108, 113].

In MEC, certain microorganisms which are capable of transferring electrons from the chamber to anode are used, known as electrogens. Shewanella spp. and Geobacter spp. are two popular electrogenic groups, out of which Shewanella oneidensis and Geobacter sulfurreducens are the most discussed species [122]. Acetobacterium woodii, Ochrobactrum anthropic, Sphingomonas strain DJ, Rhodopseudomonas palustris and Rhodoferax ferrireducens are some other exoelectrogenic species reported in recent studies [33, 122-124]. Rago et al. [125] found a high $\mathrm{H}_{2}$ yield (2.6 $\mathrm{L} \mathrm{H}_{2} / \mathrm{L}_{\text {REACTOR}} / \mathrm{d}$ ) with alkaline MEC, using Alkalibacter sp. as exoelectrogen.

\section{Biohydrogen production through gasification}

Gasification of biowaste is another way of producing bio- $\mathrm{H}_{2}$. In gasification, syngas (a mixture of $\mathrm{CO}, \mathrm{CO}_{2}, \mathrm{H}_{2}$ and $\mathrm{CH}_{4}$ ) and several by-products (tar, char, light HCs) are produced by partial oxidation of organic materials at high temperature and pressure [126]. Even though gasification is not a biological process, it is effective for organic waste conversion to hydrogen. The concentration of $\mathrm{H}_{2}$ produced during gasification can be improved by optimisation of operating parameters. Equations 17-23 show the main reactions involved during gasification.

$$
\begin{aligned}
& 2 \mathrm{C}+\mathrm{O} 2 \rightarrow 2 \mathrm{CO} \\
& \mathrm{C}+\mathrm{O}_{2} \rightarrow \mathrm{CO}_{2} \\
& \mathrm{C}+\mathrm{H}_{2} \mathrm{O} \rightarrow \mathrm{CO}+\mathrm{H}_{2} \\
& \mathrm{C}+\mathrm{CO}_{2} \rightarrow 2 \mathrm{CO}
\end{aligned}
$$


$\mathrm{C}+2 \mathrm{H}_{2} \rightarrow \mathrm{CH}_{4}$

$\mathrm{CO}+\mathrm{H}_{2} \mathrm{O} \rightarrow \mathrm{CO}_{2}+\mathrm{H}_{2}$

$\mathrm{CH}_{4}+\mathrm{H}_{2} \mathrm{O} \rightarrow \mathrm{CO}+3 \mathrm{H}_{2}$

Gasification of different types of waste materials like sewage sludge, municipal solid waste, agricultural and forest biomass, animal manure and food waste has been seen as a popular technology to produce hydrogen [33]. Prasertcharoensuk et al. [127] studied the effect of parameters on hydrogen production through lignocellulosic biomass waste gasification. $\mathrm{H}_{2}$ content in the syngas was found increasing up to $67 \mathrm{~mol} \%$ with pyrolysis temperature higher than $800{ }^{\circ} \mathrm{C}$ and $0.5-1 \mathrm{~cm}^{3}$ particle size. Su et al. [128] studied the effects of temperature $\left(400-450{ }^{\circ} \mathrm{C}\right)$, food additive $\left(\mathrm{NaHCO}_{3}, \mathrm{NaCl}\right.$ and $\mathrm{NaOH})$ and reaction time $(20-60 \mathrm{~min})$ on the supercritical water gasification of food waste. They found a maximum $\mathrm{H}_{2}$ yield of $12.73 \mathrm{~mol} / \mathrm{kg}$ with $\mathrm{NaOH}$ as a catalytic agent. Zhang et al. [129] found $28.9 \% \mathrm{H}_{2}$ content from food waste with an anaerobic digestion and gasification integrated process. Chang et al. [130] found a maximum of $29.72 \mathrm{~g} \mathrm{H}_{2} / \mathrm{kg} \mathrm{sub}-$ strate and $19.78 \mathrm{~g} \mathrm{H}_{2} / \mathrm{kg}$ substrate $\mathrm{H}_{2}$ yield with bagasse gasification and waste mushroom gasification, respectively. Shie et al. [131] studied plasma gasification of lignocellulosic municipal solid waste for $\mathrm{H}_{2}$ production. The effect of different factors like biomass type, reaction temperature, feed size, catalyst type and SB (steam-to-biomass) ratio on the $\mathrm{H}_{2}$ production in a steam gasification process is discussed by Parthasarathy and Narayanan [132]. Nanda et al. [133] studied supercritical water gasification of different agro-food residues and fruit wastes like a banana peel, Aloe vera rind, lemon peel, coconut shell, sugarcane bagasse, pineapple peel and orange peel. During the production of biodiesel, glycerol is produced in large quantities as a by-product. Recently, Osman et al. used glycerol along with the alumina foil waste using photocatalysis to produce a steady state of 4.2 millimole $\mathrm{H}_{2}$ $\mathrm{g} / \mathrm{TiO}_{2} \mathrm{hr}$., which is a promising result of multifunctional cheap photocatalytic materials for the production of green biohydrogen [134].

\section{Challenges with biohydrogen production through biological methods}

Several studies have been made so far for enhancing the economic feasibility of the $\mathrm{H}_{2}$ production process via biological methods. Although these processes have different advantages, there are many key challenges also which need to be addressed in future studies [4, 13, 33]. Table 6 describes the different advantages and challenges associated with these processes. As shown in Table 6, the biohydrogen production processes vary from process to process. The maximum yield of $\mathrm{H}_{2}$ production was found
Table 6 Advantages and challenges with biohydrogen production with biological methods

\begin{tabular}{|c|c|c|}
\hline $\begin{array}{l}\mathrm{H}_{2} \text { production } \\
\text { processes }\end{array}$ & Advantages & Challenges \\
\hline Dark fermentation & $\begin{array}{l}>\text { The utilisation of a } \\
\text { diverse, wide variety } \\
\text { of different wastes. } \\
>\mathrm{H}_{2} \text { production rate is } \\
\text { high. } \\
>\text { Reactor } \\
\text { configuration is } \\
\text { simple. }\end{array}$ & $\begin{array}{l}>\text { Separation of } \mathrm{H}_{2} \\
\text { needed from } \mathrm{CO}_{2}+\mathrm{H}_{2} \\
\text { mixture after } \\
\text { production. } \\
>\text { BOD level in the } \\
\text { effluent is high. } \\
>\text { Pre-treatment is neces- } \\
\text { sary for lignocellulosic } \\
\text { waste. }\end{array}$ \\
\hline Photofermentation & $\begin{array}{l}\triangleright \text { High COD removal } \\
\text { rate. } \\
>\text { High } \mathrm{H}_{2} \text { yield. }\end{array}$ & $\begin{array}{l}>\text { An external source of } \\
\text { light is required } \\
>\mathrm{H}_{2} \text { production rate is } \\
\text { low. } \\
>\text { The need for low light } \\
\text { conversion efficiency. } \\
>\text { Not suitable for other } \\
\text { wastes except } \\
\text { VFA-rich waste. }\end{array}$ \\
\hline Biophotolysis & $\begin{array}{l}>\text { Use of renewable } \\
\text { energy. } \\
>\text { High light } \mathrm{H}_{2} \\
\text { conversion efficiency } \\
\text { (microalgae with } \\
\text { FeFe hydrogenase). }\end{array}$ & $\begin{array}{l}>\text { A customized } \\
\text { photobioreactor is } \\
\text { required. } \\
>\mathrm{H}_{2} \text { yield is low } \\
>\text { External light source is } \\
\text { required. }\end{array}$ \\
\hline MEC & $\begin{array}{l}>\mathrm{H}_{2} \text { yield is high. } \\
>\text { High COD removal } \\
\text { rate. } \\
>\text { Suitable working } \\
\text { under room } \\
\text { temperature. }\end{array}$ & $\begin{array}{l}>\mathrm{H}_{2} \text { production rate is } \\
\text { low. } \\
>\text { The need for external } \\
\text { voltage. } \\
>\text { A catalyst is needed for } \\
\text { the electrode. }\end{array}$ \\
\hline
\end{tabular}

to be $14.2 \pm 0.2 \mathrm{~mL} / \mathrm{g} \mathrm{VSS}$, and $\mathrm{H}_{2}$ production rate was $0.13 \mathrm{~mL} / \mathrm{g} \mathrm{VSS} h$ [135]. It was found that for photofermentation, the maximum $\mathrm{H}_{2}$ yield was $642 \pm$ $22 \mathrm{~mL}$, and the maximum $\mathrm{H}_{2}$ production rate $77.78 \mathrm{~mL} /$ $\mathrm{L} / \mathrm{h}$, with an initial $\mathrm{pH}$ of 7 [136]. In another case, the effect of adding corn stalk enzymatic hydrolysate $\mathrm{H}_{2}$ yield was found to increase up to $1287.06 \mathrm{~mL} \mathrm{H}_{2} / \mathrm{g}$ TOC, and the maximum $\mathrm{H}_{2}$ production rate was found to be $10.23 \mathrm{~mL} / \mathrm{h}$ [137]. Kossalbayev et al. [98] found a maximum $\mathrm{H}_{2}$ yield of $0.348 \mu \mathrm{mol} \mathrm{H}_{2} / \mathrm{mg} \mathrm{Chl} / \mathrm{h}$ with Desertifilum sp. IPPAS B-1220. Moreover, energy conversion efficiency with biophotolysis was found to be around 2.4-4\% [22]. Jayabalan et al. [138] found a maximum $\mathrm{H}_{2}$ production rate of $4.38 \pm 0.11 \mathrm{mmol} / \mathrm{L} / \mathrm{D}$ from the sugar industry wastewater using MEC. $\mathrm{A}_{2}$ production rate of $3.48 \mathrm{~L} / \mathrm{L} / \mathrm{d}$ and an $\mathrm{H}_{2}$ yield of $511.02 \mathrm{~mL} \mathrm{H}_{2} \mathrm{~g}^{-1} \mathrm{VS}$ was reported from food waste anaerobic digestion coupled with MEC [117].

Water electrolysis is another way of producing hydrogen from water using electricity. To produce $1 \mathrm{~kg} \mathrm{H}_{2}$, around $9 \mathrm{~L}$ 
of water is needed and $8 \mathrm{~kg}$ of $\mathrm{O}_{2}$ occurs as a by-product in this process. The hydrogen produced with water electrolysis has a purity of 99.99 vol\% (strongly depending on the type of electrolysis (AEL, PEM, etc.)) [139]. Yuzer et al. [140] found a maximum hydrogen production rate of $11.4 \mathrm{mmol} / \mathrm{h}$ with the use of a bipolar membrane. They found the highest energy efficiency of $82 \%$ and an exergy efficiency of $68 \%$ with the anion exchange membrane. Chakik et al. [141] found a maximum efficiency of $99.13 \%$ with a production rate of $2.34 \mathrm{~mL} /$ min using a $\mathrm{Zn}_{95} \% \mathrm{Cr}_{5} \%$ electrode in $20 \mathrm{~g} / \mathrm{L} \mathrm{NaOH}$ solution at $0.45 \mathrm{~A}, 5 \mathrm{~V}$. Kovač et al. [142] studied $\mathrm{H}_{2}$ production with a rate of $1.138 \mathrm{~g} / \mathrm{h}$ from the electrolysis of alkaline water using solar energy.

Bio- $\mathrm{H}_{2}$ production through the biological methods, for instance, dark fermentation, can produce $\mathrm{H}_{2}$ without light along with in photofermentation, and photosynthetic bacteria can use a wide range of spectral energy. However, the energy conversion efficiency, in general, is low with 4.3 and $5.11 \%$ for dark and photofermentaion processes, respectively [21]. The major challenges herein are the low bio- $\mathrm{H}_{2}$ production rate and yield and the high cost of the raw feedstocks; thus, using organic waste materials helps to address this issue.

Overall, hydrogen can be produced from various sources, with potential supply from renewable electricity, nuclear power and lignocellulosic biomass. However, it is currently dominated by using fossil-based fuels. From biomass sources, $\mathrm{H}_{2}$ production comes mainly from anaerobic digestion, fermentation or gasification routes. While the former route is mature, it only processes specific feedstocks (food waste, sewage sludge and crops waste). While fermentation can utilise and process the non-edible cellulosic part of lignocellulosic biomass, gasification can process the whole portion of the biomass, but the technology is still not fully mature worldwide. $\mathrm{H}_{2}$ production mostly comes from natural gas and coal, while during its production globally, a greenhouse gas in the form of $\mathrm{CO}_{2}$ is released which is equivalent to the combined generated annual $\mathrm{CO}_{2}$ emissions of the UK and Indonesia with an energy consumption of 275 million tonnes of oil equivalent ( $2 \%$ of total worldwide energy demand) [10]. Thus, carbon capture and storage (CCS) is crucial when producing $\mathrm{H}_{2}$ from fossilbased fuels along with maximising our way of producing $\mathrm{H}_{2}$ from clean electricity. Currently, the International Energy Agency (IEA) reported that the technical potential of producing hydrogen from renewable electricity is expensive. However, it is expected to decrease by $30 \%$ by 2030 due to the scaling up of $\mathrm{H}_{2}$ production along with progress in renewables technology that comes with a reduction in the costing. Three major technologies could benefit from that: electrolysers (splitting water using electricity to produce $\mathrm{H}_{2}$ ), fuel cells and refuelling equipment. With the progress in solar photovoltaic and wind renewable energy technologies along with batteries, renewable electricity could provide both low- carbon electricity and low-carbon $\mathrm{H}_{2}$, as well as using electrolysis, which accounts for only $2 \%$ of the global hydrogen production now. Economically, $\mathrm{H}_{2}$ production from natural gas is the cheapest method in most of the countries around the world, such as in the Middle East which costs $\left(1 \$ / \mathrm{kg} \mathrm{H}_{2}\right)$. On the other hand, electrolysis cost is $10-40 \$ / \mathrm{MWh}$ along with full load hours of $3000-6000$, so it can compete with natural gas coupled with CCSU (carbon capture storage and utilisation). Interestingly, countries that import natural gas and have available sources of renewables or nuclear power could easily find electrolysis as an attractive option. However, the production of $\mathrm{H}_{2}$-based fuel using hydrogen as a feedstock is not economically feasible at the moment.

Overall, electrolysis is a promising route where the efficiency of the electrolyser ranges from 60 to $80 \%$, while for other green hydrogen routes such as dark fermentation, photofermentation, biophotolysis and microbial electrolysis cells, their energy conversion efficiencies are low which are $4.3,5.11,4.0$ and $11.3 \%$, respectively [21-23]. This is as a result of the complex structure of the biomass that requires complicated processing procedures during the production of green bio- $\mathrm{H}_{2}$. Also, finding the cheap feedstock of biomass is crucial herein. For instance, to meet the theoretical $\mathrm{H}_{2}$ production demand in the USA, which is $60 \mathrm{MtH}_{2}$, this would require nearly $100 \%$ of its biomass resources. However, by employing PV or wind power, only $1 \%$ or $6 \%$ will be required [143]. The factors that affect the costing of $\mathrm{H}_{2}$ production from electrolysis are the cost for the electricity, capital expenditure requirements, conversion efficiency and annual operating hours.

\section{Conclusion}

For the future of the zero-carbon economy, biohydrogen is considered a promising candidate for fossil fuel replacement due to its zero-carbon emission. This review study provides a brief critical technological discussion and analysis of the processes that are used in biohydrogen production from organic biowastes along with the factors responsible for the efficient $\mathrm{H}_{2}$ yield. Herein, raw materials, processing and production techniques and environmental influences of biohydrogen production have been reviewed. Wide varieties of biowaste materials, such as wastewaters, forest and agricultural residues, food wastes and municipal and sewage wastes, have been utilised in biohydrogen production. Regarding the high $\mathrm{H}_{2}$ yield and feedstock availability, dark fermentation, photofermentation and gasification showed clear promising results. The combined fermentation processes also have shown promising results in different studies. Pre-treatment of the substrate, $\mathrm{pH}$, temperature and hydraulic retention time (HRT) are crucial factors in regulating the optimum biohydrogen production route. The MEC method showed promising results with a good yield of biohydrogen using 
waste feedstock under low-temperature conditions. However, a large-scale production with these processes is still challenging. The need for future studies addressing more variants of microorganisms and waste varieties is highly observed. It is the authors' thought that the integration of more than one production process along with different biomass waste streams is required along with modelling to allow better processing for biohydrogen production. This would help alleviate issues concerned with fossil-based fuel, while also promoting environmental benefit as in the production of biohydrogen from sustainable waste materials and consequently working toward the zero-carbon economy.

Acknowledgements The authors would like to acknowledge the support given by the EPSRC project "Advancing Creative Circular Economies for Plastics via Technological-Social Transitions" (ACCEPT Transitions, $\mathrm{EP} / \mathrm{S} 025545 / 1)$. The authors also wish to acknowledge the support of The Bryden Centre project (Project ID VA5048) which was awarded by The European Union's INTERREG VA Programme. The authors would like to thank Charlie Farrell and Patrick McNicholl who assisted in the proofreading of the manuscript.

Open Access This article is licensed under a Creative Commons Attribution 4.0 International License, which permits use, sharing, adaptation, distribution and reproduction in any medium or format, as long as you give appropriate credit to the original author(s) and the source, provide a link to the Creative Commons licence, and indicate if changes were made. The images or other third party material in this article are included in the article's Creative Commons licence, unless indicated otherwise in a credit line to the material. If material is not included in the article's Creative Commons licence and your intended use is not permitted by statutory regulation or exceeds the permitted use, you will need to obtain permission directly from the copyright holder. To view a copy of this licence, visit http://creativecommons.org/licenses/by/4.0/.

\section{References}

1. Tausz-Posch S, De Kok LJ (2020) Plant functioning in a changing global atmosphere. Plant Biol 22:3-4

2. Fawzy S, Osman AI, Doran J, Rooney DW (2020) Strategies for mitigation of climate change: a review. Environ Chem Lett

3. Zhang Q, Dai W, Wang X, Li J (2020) Elevated CO2 concentration affects the defense of tobacco and melon against lepidopteran larvae through the jasmonic acid signaling pathway. Sci Rep 10: 4060

4. Mishra P, Krishnan S, Rana S, Singh L, Sakinah M, Ab Wahid Z (2019) Outlook of fermentative hydrogen production techniques: an overview of dark, photo and integrated dark-photo fermentative approach to biomass. Energy Strategy Reviews 24:27-37

5. https://www.co2.earth/monthly-co2, Accessed on: 5th July, 2020

6. Martins F, Felgueiras C, Smitková M (2018) Fossil fuel energy consumption in European countries. Energy Procedia 153:107111

7. Argun H, Kargi F (2010) Bio-hydrogen production from ground wheat starch by continuous combined fermentation using annularhybrid bioreactor. Int J Hydrog Energy 35:6170-6178

8. Lubitz W, Tumas W (2007) Hydrogen: an Overview. Chem Rev 107:3900-3903
9. Christopher K, Dimitrios R (2012) A review on exergy comparison of hydrogen production methods from renewable energy sources. Energy Environ Sci 5:6640-6651

10. The future of hydrogen, Report prepared by the IEA for the G20, Japan

11. Schoots K, Ferioli F, Kramer GJ, van der Zwaan BCC (2008) Learning curves for hydrogen production technology: an assessment of observed cost reductions. Int J Hydrog Energy 33:2630 2645

12. A.I. Osman, Catalytic hydrogen production from methane partial oxidation: mechanism and kinetic study, Chemical Engineering \& Technology, $\mathrm{n} / \mathrm{a}$

13. Chandrasekhar K, Lee YJ, Lee DW (2015) Biohydrogen production: strategies to improve process efficiency through microbial routes. Int J Mol Sci 16:8266-8293

14. Osman AI, Abu-Dahrieh JK, Cherkasov N, Fernandez-Garcia J, Walker D, Walton RI, Rooney DW, Rebrov E (2018) A highly active and synergistic $\mathrm{Pt} / \mathrm{Mo} 2 \mathrm{C} / \mathrm{Al} 2 \mathrm{O} 3$ catalyst for water-gas shift reaction. Molecular Catalysis 455:38-47

15. Abdul Kadir K, Wahidah N, Jamaludin S (2016) An overview of organic waste in composting. MATEC Web of Conferences 47: 05025

16. Dhanya BS, Mishra A, Chandel AK, Verma ML (2020) Development of sustainable approaches for converting the organic waste to bioenergy. Sci Total Environ 723:138109

17. Riis T, Hagen EF, Vie PJS, Ulleberg Ø, Hydrogen production R\&D - gaps and priorities - IEA HIA, https://webstore.iea.org/ download/direct/992, accessed 12-08-2020

18. Dincer I, Acar C (2015) Review and evaluation of hydrogen production methods for better sustainability. Int J Hydrog Energy 40: 11094-11111

19. Zhang Y, Angelidaki I (2014) Microbial electrolysis cells turning to be versatile technology: recent advances and future challenges. Water Res 56:11-25

20. Lin C-Y, Nguyen TM-L, Chu C-Y, Leu H-J, Lay C-H (2018) Fermentative biohydrogen production and its byproducts: a mini review of current technology developments. Renew Sust Energ Rev 82:4215-4220

21. Zhang Z, Li Y, Zhang H, He C, Zhang Q (2017) Potential use and the energy conversion efficiency analysis of fermentation effluents from photo and dark fermentative bio-hydrogen production. Bioresour Technol 245:884-889

22. Nyberg M, Heidorn T, Lindblad P (2015) Hydrogen production by the engineered cyanobacterial strain Nostoc PCC 7120 $\Delta$ hupW examined in a flat panel photobioreactor system. J Biotechnol 215:35-43

23. Zhang L, Wang Y-Z, Zhao T, Xu T (2019) Hydrogen production from simultaneous saccharification and fermentation of lignocellulosic materials in a dual-chamber microbial electrolysis cell. Int J Hydrog Energy 44:30024-30030

24. Detchusananard T, Im-orb K, Ponpesh P, Arpornwichanop A (2018) Biomass gasification integrated with $\mathrm{CO} 2$ capture processes for high-purity hydrogen production: process performance and energy analysis. Energy Convers Manag 171:1560-1572

25. Mitsushima S, Gollas B, Hacker V (2018) Chapter 1 - introduction, in: V. Hacker, S. Mitsushima (Eds.) Fuel cells and hydrogen, Elsevier, pp. 1-13

26. Tomasik P, Horton D (2012) Chapter 2 - enzymatic conversions of starch, in: D. Horton (Ed.) Advances in carbohydrate chemistry and biochemistry, Academic Press, pp. 59-436

27. Rizwan M, Shah SH, Mujtaba G, Mahmood Q, Rashid N, Shah FA (2019) Chapter 1 - ecofuel feedstocks and their prospect, in: A.K. Azad, M. Rasul (Eds.) Advanced biofuels, Woodhead Publishing, pp. 3-16

28. Mona S, Kumar SS, Kumar V, Parveen K, Saini N, Deepak B, Pugazhendhi A (2020) Green technology for sustainable 
biohydrogen production (waste to energy): a review. Sci Total Environ 138481

29. Ghimire A, Frunzo L, Pirozzi F, Trably E, Escudie R, Lens PNL, Esposito G (2015) A review on dark fermentative biohydrogen production from organic biomass: process parameters and use of by-products. Appl Energy 144:73-95

30. Hallenbeck PC (2009) Fermentative hydrogen production: principles, progress, and prognosis. Int J Hydrog Energy 34:7379-7389

31. Sarangi PK, Nanda S (2020) Biohydrogen production through dark fermentation. Chem Eng Technol 43:601-612

32. Zhou S, Pu Y, Zhang Q, Shi R, Guo X, Wang W, Ji J, Wei T, Ouyang T (2019) Microstructure and dielectric properties of high entropy $\mathrm{Ba}(\mathrm{Zr} 0.2 \mathrm{Ti} 0.2 \mathrm{Sn} 0.2 \mathrm{Hf} 0.2 \mathrm{Me} 0.2) \mathrm{O} 3$ perovskite oxides. Ceram Int

33. Tian H, Li J, Yan M, Tong YW, Wang C-H, Wang X (2019) Organic waste to biohydrogen: a critical review from technological development and environmental impact analysis perspective. Appl Energy 256:113961

34. Alibardi L, Cossu R (2016) Effects of carbohydrate, protein and lipid content of organic waste on hydrogen production and fermentation products. Waste Manag 47:69-77

35. Xing Y, Li Z, Fan Y, Hou H (2010) Biohydrogen production from dairy manures with acidification pretreatment by anaerobic fermentation. Environ Sci Pollut Res 17:392-399

36. Yang G, Wang J (2017) Enhanced hydrogen production from sewage sludge by co-fermentation with forestry wastes. Energy Fuel 31:9633-9641

37. Alemahdi N, Che Man H, Abd Rahman NA, Nasirian N, Yang Y (2015) Enhanced mesophilic bio-hydrogen production of raw rice straw and activated sewage sludge by co-digestion. Int J Hydrog Energy 40:16033-16044

38. Silva FMS, Mahler CF, Oliveira LB, Bassin JP (2018) Hydrogen and methane production in a two-stage anaerobic digestion system by co-digestion of food waste, sewage sludge and glycerol. Waste Manag 76:339-349

39. Laurinavichene T, Tekucheva D, Laurinavichius K, Tsygankov A (2018) Utilization of distillery wastewater for hydrogen production in one-stage and two-stage processes involving photofermentation. Enzym Microb Technol 110:1-7

40. Intanoo P, Chaimongkol P, Chavadej S (2016) Hydrogen and methane production from cassava wastewater using two-stage upflow anaerobic sludge blanket reactors (UASB) with an emphasis on maximum hydrogen production. Int J Hydrog Energy 41:6107-6114

41. Srivastava N, Srivastava M, Kushwaha D, Gupta VK, Manikanta A, Ramteke PW, Mishra PK (2017) Efficient dark fermentative hydrogen production from enzyme hydrolyzed rice straw by Clostridium pasteurianum (MTCC116). Bioresour Technol 238:552-558

42. Han W, Ye M, Zhu AJ, Zhao HT, Li YF (2015) Batch dark fermentation from enzymatic hydrolyzed food waste for hydrogen production. Bioresour Technol 191:24-29

43. Kim S, Choi K, Kim JO, Chung J (2013) Biological hydrogen production by anaerobic digestion of food waste and sewage sludge treated using various pretreatment technologies. Biodegradation 24:753-764

44. Silva FMS, Oliveira LB, Mahler CF, Bassin JP (2017) Hydrogen production through anaerobic co-digestion of food waste and crude glycerol at mesophilic conditions. Int J Hydrog Energy 42: 22720-22729

45. Rai PK, Singh SP, Asthana RK, Singh S (2014) Biohydrogen production from sugarcane bagasse by integrating dark- and photo-fermentation. Bioresour Technol 152:140-146

46. Estevam A, Arantes MK, Andrigheto C, Fiorini A, da Silva EA, Alves HJ (2018) Production of biohydrogen from brewery wastewater using Klebsiella pneumoniae isolated from the environment. Int J Hydrog Energy 43:4276-4283
47. Okonkwo O, Papirio S, Trably E, Escudie R, Lakaniemi A-M, Esposito G (2020) Enhancing thermophilic dark fermentative hydrogen production at high glucose concentrations via bioaugmentation with Thermotoga neapolitana. Int J Hydrog Energy 45: 17241-17249

48. Soto LR, Byrne E, van Niel EWJ, Sayed M, Villanueva CC, HattiKaul R (2019) Hydrogen and polyhydroxybutyrate production from wheat straw hydrolysate using Caldicellulosiruptor species and Ralstonia eutropha in a coupled process. Bioresour Technol 272:259-266

49. Łukajtis R, Hołowacz I, Kucharska K, Glinka M, Rybarczyk P, Przyjazny A, Kamiński M (2018) Hydrogen production from biomass using dark fermentation. Renew Sust Energ Rev 91:665-694

50. Eskicioglu C, Monlau F, Barakat A, Ferrer I, Kaparaju P, Trably E, Carrère $H$ (2017) Assessment of hydrothermal pretreatment of various lignocellulosic biomass with $\mathrm{CO} 2$ catalyst for enhanced methane and hydrogen production. Water Res 120:32-42

51. Yin Y, Wang J (2015) Biohydrogen production using waste activated sludge disintegrated by gamma irradiation. Appl Energy 155:434-439

52. Leaño EP, Babel S (2012) The influence of enzyme and surfactant on biohydrogen production and electricity generation using palm oil mill effluent. J Clean Prod 31:91-99

53. Guo P, Mochidzuki K, Cheng W, Zhou M, Gao H, Zheng D, Wang X, Cui Z (2011) Effects of different pretreatment strategies on corn stalk acidogenic fermentation using a microbial consortium. Bioresour Technol 102:7526-7531

54. Gonzales RR, Kim S-H (2017) Dark fermentative hydrogen production following the sequential dilute acid pretreatment and enzymatic saccharification of rice husk. Int J Hydrog Energy 42: $27577-27583$

55. Cao G-L, Guo W-Q, Wang A-J, Zhao L, Xu C-J, Zhao Q-1, Ren N-Q (2012) Enhanced cellulosic hydrogen production from limetreated cornstalk wastes using thermophilic anaerobic microflora. Int J Hydrog Energy 37:13161-13166

56. Song W, Ding L, Liu M, Cheng J, Zhou J, Li Y-Y (2020) Improving biohydrogen production through dark fermentation of steam-heated acid pretreated Alternanthera philoxeroides by mutant Enterobacter aerogenes ZJU1. Sci Total Environ 716:134695

57. Shao W, Wang Q, Rupani PF, Krishnan S, Ahmad F, Rezania S, Rashid MA, Sha C, Md Din MF (2020) Biohydrogen production via thermophilic fermentation: a prospective application of Thermotoga species. Energy 197:117199

58. Li C, Fang HHP (2007) Fermentative hydrogen production from wastewater and solid wastes by mixed cultures. Crit Rev Environ Sci Technol 37:1-39

59. Azbar N, Dokgöz FT, Keskin T, Eltem R, Korkmaz KS, Gezgin Y, Akbal Z, Öncel S, Dalay MC, Gönen Ç, Tutuk F (2009) Comparative evaluation of bio-hydrogen production from cheese whey wastewater under thermophilic and mesophilic anaerobic conditions. Int J Green Energy 6:192-200

60. Guo XM, Trably E, Latrille E, Carrère H, Steyer J-P (2010) Hydrogen production from agricultural waste by dark fermentation: a review. Int J Hydrog Energy 35:10660-10673

61. Rafieenia R, Lavagnolo MC, Pivato A (2018) Pre-treatment technologies for dark fermentative hydrogen production: current advances and future directions. Waste Manag 71:734-748

62. Mamimin C, Singkhala A, Kongjan P, Suraraksa B, Prasertsan P, Imai T, O-Thong S (2015) Two-stage thermophilic fermentation and mesophilic methanogen process for biohythane production from palm oil mill effluent. Int J Hydrog Energy 40:6319-6328

63. Kumar G, Zhen G, Sivagurunathan P, Bakonyi P, Nemestóth N, Bélafi-Bakó K, Kobayashi T, Xu KQ (2016) Biogenic H2 production from mixed microalgae biomass: impact of $\mathrm{pH}$ control and methanogenic inhibitor (BESA) addition. Biofuel Res J 11:470-474 
64. Chandrasekhar K, Venkata Mohan S (2014) Bio-electrohydrolysis as a pretreatment strategy to catabolize complex food waste in closed circuitry: function of electron flux to enhance acidogenic biohydrogen production. Int J Hydrog Energy 39:11411-11422

65. Tsygankov DNTAA (2011) Integration of biological H2 producing processes, State of the art and progress in production of bio hydrogen, Bentham Science Publishers Ltd, USA; Chapter 5:pp. 78-93

66. Santiago SG, Morgan-Sagastume JM, Monroy O, MorenoAndrade I (2019) Biohydrogen production from organic solid waste in a sequencing batch reactor: an optimization of the hydraulic and solids retention time. Int J Hydrog Energy

67. Lu C, Wang Y, Lee D-J, Zhang Q, Zhang H, Tahir N, Jing Y, Liu $\mathrm{H}$, Zhang K (2019) Biohydrogen production in pilot-scale fermenter: effects of hydraulic retention time and substrate concentration. J Clean Prod 229:751-760

68. Colombo B, Villegas Calvo M, Pepè Sciarria T, Scaglia B, Savio Kizito S, D'Imporzano G, Adani F (2019) Biohydrogen and polyhydroxyalkanoates (PHA) as products of a two-steps bioprocess from deproteinized dairy wastes. Waste Manag 95:22-31

69. Monroy I, Buitrón G (2020) Production of polyhydroxybutyrate by pure and mixed cultures of purple non-sulfur bacteria: a review. J Biotechnol 317:39-47

70. Das D (2009) Advances in biohydrogen production processes: an approach towards commercialization. Int J Hydrog Energy 34: 7349-7357

71. Ni M, Leung DYC, Leung MKH, Sumathy K (2006) An overview of hydrogen production from biomass. Fuel Process Technol 87: 461-472

72. Cai J, Zhao Y, Fan J, Li F, Feng C, Guan Y, Wang R, Tang N (2019) Photosynthetic bacteria improved hydrogen yield of combined dark- and photo-fermentation. J Biotechnol 302:18-25

73. Azwar MY, Hussain MA, Abdul-Wahab AK (2014) Development of biohydrogen production by photobiological, fermentation and electrochemical processes: a review. Renew Sust Energ Rev 31:158-173

74. Mirza SS, Qazi JI, Liang Y, Chen S (2019) Growth characteristics and photofermentative biohydrogen production potential of purple non sulfur bacteria from sugar cane bagasse. Fuel 255:115805

75. García-Sánchez R, Ramos-Ibarra R, Guatemala-Morales G, Arriola-Guevara E, Toriz-González G, Corona-González RI (2018) Photofermentation of tequila vinasses by Rhodopseudomonas pseudopalustris to produce hydrogen. Int $\mathrm{J}$ Hydrog Energy 43:15857-15869

76. Machado RG, Moreira FS, Batista FRX, Ferreira JS, Cardoso VL (2018) Repeated batch cycles as an alternative for hydrogen production by co-culture photofermentation. Energy 153:861-869

77. Keskin T, Hallenbeck PC (2012) Hydrogen production from sugar industry wastes using single-stage photofermentation. Bioresour Technol 112:131-136

78. Lu C, Zhang Z, Ge X, Wang Y, Zhou X, You X, Liu H, Zhang Q (2016) Bio-hydrogen production from apple waste by photosynthetic bacteria HAU-M1. Int J Hydrog Energy 41:13399-13407

79. Mishra P, Thakur S, Singh L, Ab Wahid Z, Sakinah M (2016) Enhanced hydrogen production from palm oil mill effluent using two stage sequential dark and photo fermentation. Int J Hydrog Energy 41:18431-18440

80. Zhang Q, Zhang Z, Wang Y, Lee D-J, Li G, Zhou X, Jiang D, Xu B, Lu C, Li Y, Ge X (2018) Sequential dark and photo fermentation hydrogen production from hydrolyzed corn stover: a pilot test using $11 \mathrm{~m} 3$ reactor. Bioresour Technol 253:382-386

81. Sagir E, Ozgur E, Gunduz U, Eroglu I, Yucel M (2017) Singlestage photofermentative biohydrogen production from sugar beet molasses by different purple non-sulfur bacteria. Bioprocess Biosyst Eng 40:1589-1601

82. Jiang D, Ge X, Zhang T, Liu H, Zhang Q (2016) Photofermentative hydrogen production from enzymatic hydrolysate of corn stalk pith with a photosynthetic consortium. Int $\mathbf{J}$ Hydrog Energy 41:16778-16785

83. Xia A, Cheng J, Ding L, Lin R, Song W, Zhou J, Cen K (2014) Enhancement of energy production efficiency from mixed biomass of Chlorella pyrenoidosa and cassava starch through combined hydrogen fermentation and methanogenesis. Appl Energy 120:23-30

84. Hitit ZY, Lazaro CZ, Hallenbeck PC (2017) Single stage hydrogen production from cellulose through photo-fermentation by a co-culture of Cellulomonas fimi and Rhodopseudomonas palustris. Int J Hydrog Energy 42:6556-6566

85. Al-Mohammedawi HH, Znad H, Eroglu E (2019) Improvement of photofermentative biohydrogen production using pre-treated brewery wastewater with banana peels waste. Int J Hydrog Energy 44:2560-2568

86. Jiang D, Ge X, Lin L, Zhang T, Liu H, Hu J, Zhang Q (2020) Continuous photo-fermentative hydrogen production in a tubular photobioreactor using corn stalk pith hydrolysate with a consortium. Int J Hydrog Energy 45:3776-3784

87. Mrynat ME, Ören İ, Özkan E, Argun H (2020) Sequential dark and photo-fermentative hydrogen gas production from agar embedded molasses. Int J Hydrog Energy

88. Zhu S, Zhang Z, Li Y, Tahir N, Liu H, Zhang Q (2018) Analysis of shaking effect on photo-fermentative hydrogen production under different concentrations of corn stover powder. Int J Hydrog Energy 43:20465-20473

89. Ghosh S, Dairkee UK, Chowdhury R, Bhattacharya P (2017) Hydrogen from food processing wastes via photofermentation using purple non-sulfur bacteria (PNSB) - a review. Energy Convers Manag 141:299-314

90. Nagakawa H, Takeuchi A, Takekuma Y, Noji T, Kawakami K, Kamiya N, Nango M, Furukawa R, Nagata M (2019) Efficient hydrogen production using photosystem I enhanced by artificial light harvesting dye. Photochem Photobiol Sci 18:309-313

91. Fakhimi N, Tavakoli O (2019) Improving hydrogen production using co-cultivation of bacteria with Chlamydomonas reinhardtii microalga. Mater Sci Energy Technol 2:1-7

92. Hoshino T, Johnson DJ, Scholz M, Cuello JL (2013) Effects of implementing PSI-light on hydrogen production via biophotolysis in Chlamydomonas reinhardtii mutant strains. Biomass Bioenergy 59:243-252

93. Volgusheva A, Kukarskikh G, Krendeleva T, Rubin A, Mamedov F (2015) Hydrogen photoproduction in green algae Chlamydomonas reinhardtii under magnesium deprivation. RSC Adv 5:5633-5637

94. Batyrova K, Gavrisheva A, Ivanova E, Liu J, Tsygankov A (2015) Sustainable hydrogen photoproduction by phosphorus-deprived marine green microalgae Chlorella sp. Int J Mol Sci 16:2705-2716

95. Shi X-Y, Yu H-Q (2016) Simultaneous metabolism of benzoate and photobiological hydrogen production by Lyngbya sp. Renew Energy 95:474-477

96. Oncel S, Kose A (2014) Comparison of tubular and panel type photobioreactors for biohydrogen production utilizing Chlamydomonas reinhardtii considering mixing time and light intensity. Bioresour Technol 151:265-270

97. Kosourov SN, Ghirardi ML, Seibert M (2011) A truncated antenna mutant of Chlamydomonas reinhardtii can produce more hydrogen than the parental strain. Int J Hydrog Energy 36:2044-2048

98. Kossalbayev BD, Tomo T, Zayadan BK, Sadvakasova AK, Bolatkhan K, Alwasel S, Allakhverdiev SI (2020) Determination of the potential of cyanobacterial strains for hydrogen production. Int J Hydrog Energy 45:2627-2639

99. Esquível MG, Amaro HM, Pinto TS, Fevereiro PS, Malcata FX (2011) Efficient H2 production via Chlamydomonas reinhardtii. Trends Biotechnol 29:595-600

100. Kosourov S, Seibert M, Ghirardi ML (2003) Effects of extracellular $\mathrm{pH}$ on the metabolic pathways in sulfur-deprived, $\mathrm{H} 2$ - 
producing Chlamydomonas reinhardtii cultures. Plant Cell Physiol 44:146-155

101. Huesemann MH, Hausmann TS, Carter BM, Gerschler JJ, Benemann JR (2010) Hydrogen generation through indirect biophotolysis in batch cultures of the nonheterocystous nitrogenfixing cyanobacterium Plectonema boryanum. Appl Biochem Biotechnol 162:208-220

102. Kadier A, Simayi Y, Abdeshahian P, Azman NF, Chandrasekhar K, Kalil MS (2016) A comprehensive review of microbial electrolysis cells (MEC) reactor designs and configurations for sustainable hydrogen gas production. Alex Eng J 55:427-443

103. Yossan S, Xiao L, Prasertsan P, He Z (2013) Hydrogen production in microbial electrolysis cells: choice of catholyte. Int J Hydrog Energy 38:9619-9624

104. Luo S, Jain A, Aguilera A, He Z (2017) Effective control of biohythane composition through operational strategies in an innovative microbial electrolysis cell. Appl Energy 206:879-886

105. Heidrich ES, Dolfing J, Scott K, Edwards SR, Jones C, Curtis TP (2013) Production of hydrogen from domestic wastewater in a pilot-scale microbial electrolysis cell. Appl Microbiol Biotechnol 97:6979-6989

106. Cheng S, Logan BE (2007) Sustainable and efficient biohydrogen production via electrohydrogenesis. Proc Natl Acad Sci 104: 18871-18873

107. Wang A, Sun D, Cao G, Wang H, Ren N, Wu W-M, Logan BE (2011) Integrated hydrogen production process from cellulose by combining dark fermentation, microbial fuel cells, and a microbial electrolysis cell. Bioresour Technol 102:4137-4143

108. Shen R, Jiang Y, Ge Z, Lu J, Zhang Y, Liu Z, Ren ZJ (2018) Microbial electrolysis treatment of post-hydrothermal liquefaction wastewater with hydrogen generation. Appl Energy 212:509-515

109. Wagner RC, Regan JM, Oh S-E, Zuo Y, Logan BE (2009) Hydrogen and methane production from swine wastewater using microbial electrolysis cells. Water Res 43:1480-1488

110. Escapa A, Gil-Carrera L, García V, Morán A (2012) Performance of a continuous flow microbial electrolysis cell (MEC) fed with domestic wastewater. Bioresour Technol 117:55-62

111. Cusick RD, Kiely PD, Logan BE (2010) A monetary comparison of energy recovered from microbial fuel cells and microbial electrolysis cells fed winery or domestic wastewaters. Int J Hydrog Energy 35:8855-8861

112. Liu W, Huang S, Zhou A, Zhou G, Ren N, Wang A, Zhuang G (2012) Hydrogen generation in microbial electrolysis cell feeding with fermentation liquid of waste activated sludge. Int J Hydrog Energy 37:13859-13864

113. Feng Y, Liu Y, Zhang Y (2015) Enhancement of sludge decomposition and hydrogen production from waste activated sludge in a microbial electrolysis cell with cheap electrodes. Environ Sci Water Res Technol 1:761-768

114. Lu L, Xing D, Liu B, Ren N (2012) Enhanced hydrogen production from waste activated sludge by cascade utilization of organic matter in microbial electrolysis cells. Water Res 46:1015-1026

115. Dhar BR, Elbeshbishy E, Hafez H, Lee H-S (2015) Hydrogen production from sugar beet juice using an integrated biohydrogen process of dark fermentation and microbial electrolysis cell. Bioresour Technol 198:223-230

116. Tenca A, Cusick RD, Schievano A, Oberti R, Logan BE (2013) Evaluation of low cost cathode materials for treatment of industrial and food processing wastewater using microbial electrolysis cells. Int J Hydrog Energy 38:1859-1865

117. Huang J, Feng H, Huang L, Ying X, Shen D, Chen T, Shen X, Zhou Y, Xu Y (2020) Continuous hydrogen production from food waste by anaerobic digestion (AD) coupled single-chamber microbial electrolysis cell (MEC) under negative pressure. Waste Manag 103:61-66
118. Li X-H, Liang D-W, Bai Y-X, Fan Y-T, Hou H-W (2014) Enhanced $\mathrm{H} 2$ production from corn stalk by integrating dark fermentation and single chamber microbial electrolysis cells with double anode arrangement. Int J Hydrog Energy 39:8977-8982

119. Shen R, Liu Z, He Y, Zhang Y, Lu J, Zhu Z, Si B, Zhang C, Xing X-H (2016) Microbial electrolysis cell to treat hydrothermal liquefied wastewater from cornstalk and recover hydrogen: degradation of organic compounds and characterization of microbial community. Int J Hydrog Energy 41:4132-4142

120. Heidrich ES, Edwards SR, Dolfing J, Cotterill SE, Curtis TP (2014) Performance of a pilot scale microbial electrolysis cell fed on domestic wastewater at ambient temperatures for a 12month period. Bioresour Technol 173:87-95

121. Patil SA, Harnisch F, Kapadnis B, Schröder U (2010) Electroactive mixed culture biofilms in microbial bioelectrochemical systems: the role of temperature for biofilm formation and performance. Biosens Bioelectron 26:803-808

122. Kumar R, Singh L, Zularisam AW (2016) Exoelectrogens: recent advances in molecular drivers involved in extracellular electron transfer and strategies used to improve it for microbial fuel cell applications. Renew Sust Energ Rev 56:1322-1336

123. Zhen G, Lu X, Kumar G, Bakonyi P, Xu K, Zhao Y (2017) Microbial electrolysis cell platform for simultaneous waste biorefinery and clean electrofuels generation: current situation, challenges and future perspectives. Prog Energy Combust Sci 63:119-145

124. Karthikeyan R, Cheng KY, Selvam A, Bose A, Wong JWC (2017) Bioelectrohydrogenesis and inhibition of methanogenic activity in microbial electrolysis cells - a review. Biotechnol Adv 35:758-771

125. Rago L, Baeza JA, Guisasola A (2016) Increased performance of hydrogen production in microbial electrolysis cells under alkaline conditions. Bioelectrochemistry 109:57-62

126. Abdoulmoumine N, Adhikari S, Kulkarni A, Chattanathan S (2015) A review on biomass gasification syngas cleanup. Appl Energy 155:294-307

127. Prasertcharoensuk P, Bull SJ, Phan AN (2019) Gasification of waste biomass for hydrogen production: effects of pyrolysis parameters. Renew Energy 143:112-120

128. Su W, Cai C, Liu P, Lin W, Liang B, Zhang H, Ma Z, Ma H, Xing Y, Liu W (2020) Supercritical water gasification of food waste: effect of parameters on hydrogen production. Int J Hydrog Energy 45:14744-14755

129. Zhang J, Hu Q, Qu Y, Dai Y, He Y, Wang C-H, Tong YW (2020) Integrating food waste sorting system with anaerobic digestion and gasification for hydrogen and methane co-production. Appl Energy 257:113988

130. Chang ACC, Chang H-F, Lin F-J, Lin K-H, Chen C-H (2011) Biomass gasification for hydrogen production. Int $\mathrm{J}$ Hydrog Energy 36:14252-14260

131. Shie J-L, Chen L-X, Lin K-L, Chang C-Y (2014) Plasmatron gasification of biomass lignocellulosic waste materials derived from municipal solid waste. Energy 66:82-89

132. Parthasarathy P, Narayanan KS (2014) Hydrogen production from steam gasification of biomass: influence of process parameters on hydrogen yield - a review. Renew Energy 66:570-579

133. Nanda S, Isen J, Dalai AK, Kozinski JA (2016) Gasification of fruit wastes and agro-food residues in supercritical water. Energy Convers Manag 110:296-306

134. Osman AI, Skillen NC, Robertson PKJ, Rooney DW, Morgan K (2020) Exploring the photocatalytic hydrogen production potential of titania doped with alumina derived from foil waste. Int $\mathbf{J}$ Hydrog Energy

135. Wang Y, Wang D, Chen F, Yang Q, Li Y, Li X, Zeng G (2019) Effect of triclocarban on hydrogen production from dark fermentation of waste activated sludge. Bioresour Technol 279:307-316 
136. Hu B, Li Y, Zhu S, Zhang H, Jing Y, Jiang D, He C, Zhang Z (2020) Evaluation of biohydrogen yield potential and electron balance in the photo-fermentation process with different initial $\mathrm{pH}$ from starch agricultural leftover. Bioresour Technol 305:122900

137. Li Y, Zhang Z, Zhang Q, Tahir N, Jing Y, Xia C, Zhu S, Zhang X (2020) Enhancement of bio-hydrogen yield and $\mathrm{pH}$ stability in photo fermentation process using dark fermentation effluent as succedaneum. Bioresour Technol 297:122504

138. Jayabalan T, Matheswaran M, Preethi V, Naina Mohamed S (2020) Enhancing biohydrogen production from sugar industry wastewater using metal oxide/graphene nanocomposite catalysts in microbial electrolysis cell. Int J Hydrog Energy 45:7647-7655

139. Ursua A, Gandia LM, Sanchis P (2012) Hydrogen production from water electrolysis: current status and future trends. Proc IEEE 100:410-426
140. Yuzer B, Selcuk H, Chehade G, Demir ME, Dincer I (2020) Evaluation of hydrogen production via electrolysis with ion exchange membranes. Energy 190:116420

141. Chakik FE, Kaddami M, Mikou M (2017) Effect of operating parameters on hydrogen production by electrolysis of water. Int J Hydro Energy 42:25550-25557

142. Kovač A, Marciuš D, Budin L (2019) Solar hydrogen production via alkaline water electrolysis. Int J Hydrog Energy 44:9841-9848

143. Ruth MF, Jadun P, Pivovar B (2017) "H2@Scale: technical and economic potential of hydrogen as an energy intermediate", Presentation at the Fuel Cell Seminar and Energy Exposition, Long Beach, CA, 9 November, https://doi.org/10.5065/D6M32STK.

Publisher's Note Springer Nature remains neutral with regard to jurisdictional claims in published maps and institutional affiliations. 